\title{
Key issues in the welfare of dairy cattle
}

Jan Hultgren, Swedish University of Agricultural Sciences, Sweden

1 Introduction: an overview of interest in and determinants of animal welfare in dairy farming

2 Husbandry practices in dairy farming: housing, handling and farming procedures

3 Husbandry practices in dairy farming: health, productivity and breeding

4 Applying different perspectives on animal welfare to the case of dairy farming

5 Recommendations for improving animal welfare in dairy farming in the light of expected future developments

6 Summary

7 Where to look for further information

8 Acknowledgements

9 References

\section{Introduction: an overview of interest in and determinants of animal welfare in dairy farming}

\subsection{Interest in animal welfare in dairy farming}

Concern about the welfare of dairy cattle is widespread. It is based on beliefs that animal well-being matters and that humans have responsibilities towards the animals in their care. This has always been recognized by people committed to the care of dairy cattle, inspiring management practices, education, publications, campaigns, guidelines and legislation throughout the history of milk farming. The more recent scientific interest in animal welfare stems largely from a public concern about modern methods and techniques in farm animal husbandry, including farming for milk.

With industrialization and rationalization efforts during the last century, including changes in infrastructure, feed imports, innovations in animal genetics, breeding and mechanization of work, production systems have become more confined, and dairy farms more sparsely scattered and larger. Relating the number of dairy holdings in a country to the number of inhabitants may highlight this trend (Fig. 1). The average herd size is today well above a hundred cows in a number of countries (Anon., 2013c; Fig. 2). Farms with several tens of thousands of cows are seen in the United States, Saudi Arabia and China, and mega dairies of 100000 cows will soon become a reality. 


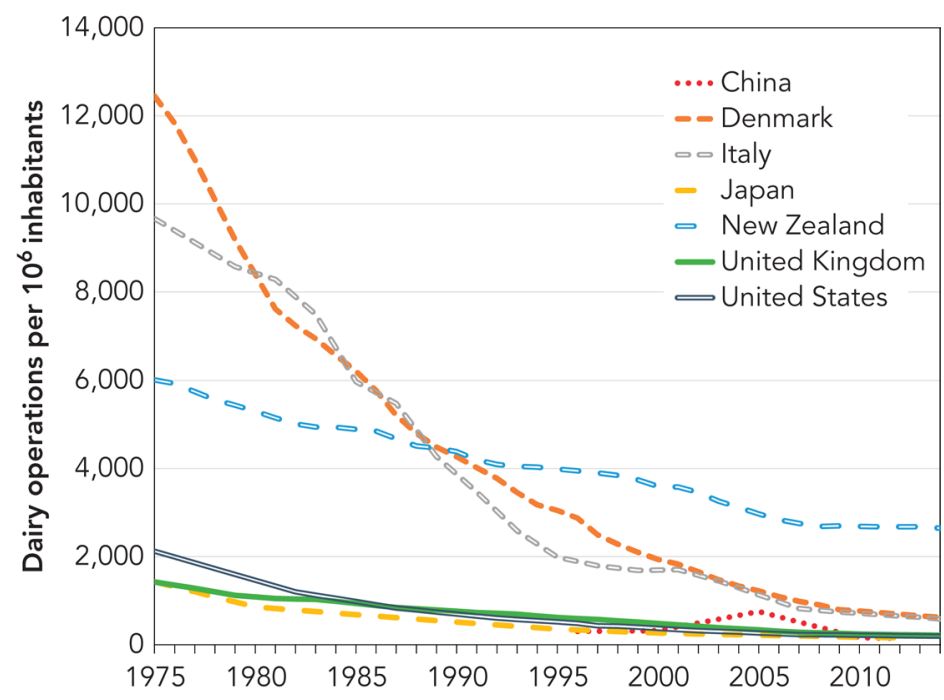

Figure 1 Selected national statistics of the number of dairy holdings per million inhabitants 1975-2014 (Anon., 2010c, 2013a,b,c, 2015a,b, 2016e,g,h,i,k). Data from different countries may not be directly comparable.

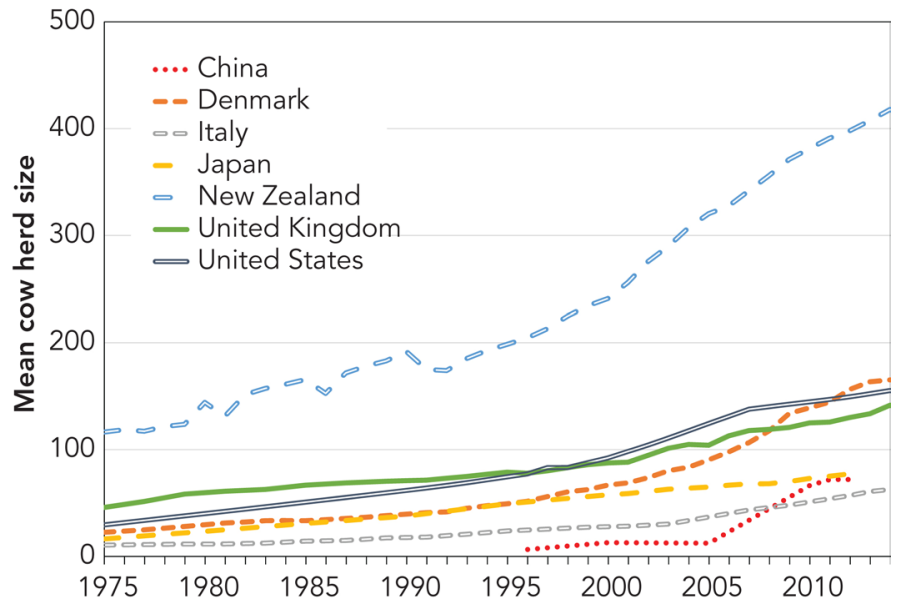

Figure 2 Selected national statistics of mean dairy herd size 1975-2014 (Anon., 2010c, 2013a,b,c, $2015 a, b, 2016 e, g, h, i, k)$. Data from different countries may not be directly comparable.

At the beginning of the 1900s, European and North American dairy cows were generally tethered in tie-stalls when kept indoors in wintertime (Bickert, 2003), but loose housing with cubicles (free-stalls) is today the predominant way of keeping cows in large dairy operations. Nonetheless, tie-stalls are still fairly common, especially in smaller herds. In Europe and North America, dairy cows are often kept indoors permanently or kept on 
outdoor dry lots with little or no access to pasture, and this is the so-called zero-grazing. In New Zealand, Australia, Ireland and South America, on the other hand, intensive dairy cattle systems involve grasslands and pastures.

During a half-century of structural and technological innovation, milk yields have more than doubled (Anon., 2016f,i). Milk production has thus intensified in three different ways; more confined systems, fewer units and higher yields. Arguably, the profitability of milk farming enterprises and a quest for efficiency have been the main drivers for intensification. This trend continues today.

Parallel to the intensification of milk production, urbanization has seen rapid growth, which has created a human population with limited experience of farm animals. For the first time in modern history, large groups of people seem ignorant of food animal production and lack basic understanding of the terms of intensive milk farming. Nonetheless, the concern for farm animal welfare has increased and now seems to be greater than ever. Many citizens demand to be assured that food animals have a decent life and be killed in a humane way when their productive life is over.

Globally, about three-quarters of all dairy operations are household farms with 1-3 cows and these households sell milk for cash or consume it to fulfil daily needs (Anon., 2010c). Nevertheless, because of the challenges that the intensification of milk production has brought about, this chapter looks into key issues in the welfare of specialized dairy cattle on family farms or corporate dairies in intensive production, together producing most of the milk in the world, albeit representing a minority of the global cow population.

\subsection{Determinants of animal welfare}

Several factors determine the welfare of dairy cattle. Some of these relate to the environment that surrounds dairy farms and animals, such as climatic conditions, pasture vegetation and wildlife. Others follow from contacts with conspecifics on farm. Some major challenges to animal well-being are even inherent to life itself and therefore cannot be avoided altogether. In many ways, however, animal welfare is a consequence of the husbandry conditions. Housing and handling have a major impact through confinement and other limiting conditions for the animals, but also by protecting them from harmful influences of other animals or the environment, which arguably puts a great responsibility on the stockperson or animal caretaker. Many of the determinants of the welfare of dairy cattle are dealt with in other texts, as well as the remaining chapters of this volume. This section highlights some of the most important issues.

Due to the complex nature of animal welfare, its determinants are entangled in a multidimensional web of mutual dependencies (Anon., 2012c). Heritage and previous experiences will determine the basic conditions, that is, physical capacities, ability to contentment, and susceptibility to external influences. The animal may be exposed to a risk factor for poor welfare for a very short time period, which may have a decisive, adverse or favourable impact for the rest of its life. For example, trauma may cause permanent injury, and forced premature separation from the mother can cause long-term behavioural changes and possibly mental suffering to a calf (Stěhulová et al., 2008; Gaillard et al., 2014). Conversely, good treatment early in life can have favourable effects on animal welfare much later. For example, animals reared together from birth show less aggressive interactions towards each other even after one year of being grouped with other animals and are more tolerant in competitive situations compared to animals reared separately (Bouissou and Andrieu, 1978). 
Moreover, welfare determinants often interact by moderating (strengthening or weakening) each other's effects. For example, an animal heavily contaminated with manure can be more sensitive to low temperatures (Anon., 2009d), and stress from high production or social submissiveness can increase its susceptibility to infectious disease (Ingvartsen et al., 2003; Proudfoot et al., 2012).

Finally, different aspects of bad (or good) animal welfare can arise in several ways by exposure to what appears to be a single determinant, sometimes as an indirect effect long after exposure to the determinant. For example, a faulty stall design restricts the animals' movements more than necessary, which can make the stall floor and animals dirty, which in turn will increase the risk of mastitis and hoof disease, which will ultimately increase the likelihood of culling at the end of lactation. In this case, the faulty stall design may be regarded as the primary determinant in a long chain of events. Along the chain, poor animal welfare results from, for example, restricted movements (abnormal behaviour, frustration, injury), contamination with manure (discomfort, pain, skin disease, reduced function), udder infection (pain, malaise, reduced function), hoof infection (pain, lameness, reduced function) and culling (reduced lifetime). In this way, cause and effect are inextricably linked and become practically indistinguishable. It is not even obvious what the primary welfare determinant is (Fig. 3).

If the severity of poor welfare is plotted against time, an overall estimate of welfare is the area under the curve thus produced (Broom, 2001). An example of this is given in Fig. 4. In connection with dehorning of calves, the absence of analgesic treatment results in a negative welfare response, as indicated by elevated blood cortisol concentrations during ten hours following treatment. A local anaesthetic improves total welfare (smaller area under curve) but postpones the negative response, resulting in high cortisol levels

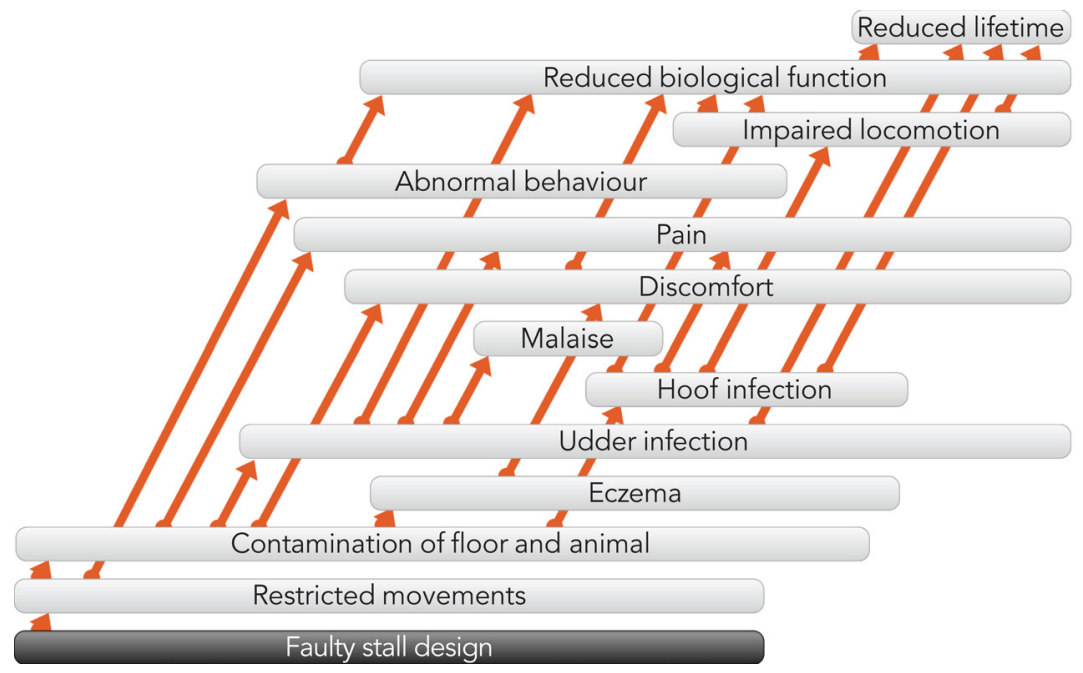

Figure 3 Example of plausible relationships between different determinants and manifestations of animal welfare, represented by boxes and related to feelings (e.g. discomfort, pain), biological function (e.g. udder infection, impaired locomotion) or natural life (e.g. behaviour, lifetime). Time goes from left to right, box width indicates duration and the arrows represent alleged causal links. Most of the determinants are also manifestations, and vice versa. 


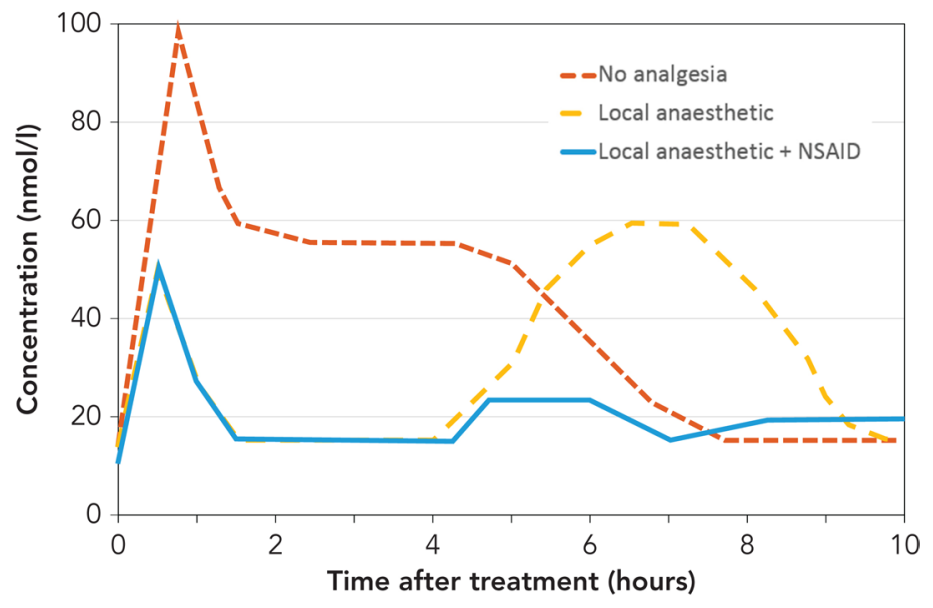

Figure 4 Example of changes in calf welfare, as indicated by cortisol concentration in blood, in response to dehorning of calves with no analgesia, a local anaesthetic and a local anaesthetic combined with a nonsteroidal anti-inflammatory drug (modified from Stafford and Mellor, 2005).

six to nine hours after treatment. The combination of a local anaesthetic and an antiinflammatory drug appears most favourable (smallest area under curve).

\section{Husbandry practices in dairy farming: housing, handling and farming procedures}

\subsection{Confinement and restricted movement}

Tie-stalls restrict the freedom of movement and tied animals are almost completely deprived of exercise. Depending on the type of tie-stalls, they are also partly prevented from performing self-grooming. Furthermore, subdominant individuals are unable to move away from dominant neighbours. On the other hand, cows in tie-stalls do not have to compete as much for resources like feed, water and a lying place, compared to loosehoused cows, and it may be easier to give them individual care. Cows are motivated to walk and tethering thwarts this motivation, although the animals not necessarily show a physiological stress response (Veissier et al., 2008).

According to the European Food Safety Authority (EFSA) (Anon., 2009d), tie-stall housing compromises the welfare of dairy cattle, comparing with open, bedded packs. However, EFSA did not consider free-stall housing associated with an increased incidence of leg and locomotor disorders as favourable as tie-stalls. Popescu et al. $(2013,2014)$ found that loose housing (in cubicles or a straw yard) in Romania have welfare advantages compared to tie-stalls, but they also concluded that welfare is not necessarily poorer in tie-stall housing. Lower incidences of a number of diseases have been found in cubicles than in tie-stalls in Norway, although this difference was not so clear for small free-stall operation (Simensen et al., 2010). 
At pasture, cows can move freely on a relatively clean and dry surface, and a large number of studies indicate that seasonal pasture is beneficial to cow health. For example, pasture access is associated with a lowered risk for leg and foot lesions, and lameness (Haskell et al., 2006; Hernandez-Mendo, 2007; Rutherford et al., 2008; Bergman et al., 2014). Barkema et al. (1999) and Washburn et al. (2002) found a reduced incidence of mastitis in herds with access to pasture. According to EFSA (Anon., 2009d), access to pasture reduces the risk for hoof diseases, lameness, teat tramping, mastitis, acute metritis, dystocia, ketosis, retained placenta and various bacterial infections. Danish and Swedish studies have also shown a reduced mortality risk in herds with more pasture access (Thomsen et al., 2007; Burow et al., 2011; Alvåsen et al., 2014). There is evidence that cattle prefer access to pasture, but this preference depends on the time of day and the weather conditions; cattle avoid bright sunshine and high temperatures (Legrand et al., 2009; Charlton et al., 2013).

In some regions, especially densely populated areas where cultivated land is scarce, or where regulations on ammonia emission or nutrient leakage are placed on livestock farmers that limit their use of pastures, cows are kept indoors all-year round, and this is so-called zero-grazing. Astrid Lindgren, the famous Swedish author of children's stories, argued for the right of cattle to have outdoor access during summer, and she exercised some influence on the Swedish animal welfare legislation issued in 1988 in this regard. The practice of zero-grazing tends to increase, although reliable information is scarce. EFSA (Anon., 2009d) recognized zero-grazing as a major animal welfare issue, although it received a low risk score while being estimated as a relatively uncommon practice in Europe.

\subsection{Disruption of social structures}

Cattle fall under the category of social animals. As pointed out by EFSA, the social environment in early life and the management of grouping during rearing may have long-term effects on animal welfare, but has commonly not received attention in practice (Anon., 2009d). Groups of cattle develop a social hierarchy which determines priority of access to resources. Fraser and Broom (1990) estimated the number of cattle that can be recognized and remembered by an individual to 50-70, a group size frequently exceeded in large dairies. Although research on this topic is scarce, mixing of animals and very large groups disrupt the social structures, thus inducing the possibility of aggression; however, the level of aggression and stress during the introduction of unfamiliar animals into a herd seems to depend on specific management practices or particular circumstances (Menke et al., 1999). Frequent regrouping of livestock may also increase exposure to pathogens and prolong disease outbreaks.

Social isolation causes severe stress in heifers and the mere sight of conspecifics reduces behavioural distress (Boissy and Le Neindre, 1997). Most dairy calves are separated from their mothers at an early age, often immediately after birth, to be reared individually, in pairs or in larger groups. The welfare consequences of this practice have been subject to a considerable amount of research (Flower and Weary, 2003; Johnsen et al., 2016).

Independently of nursing, calf and dam form bonds (Johnsen et al., 2015). Consequently, both react behaviourally to separation. The response is more intense and lasts longer when separation is delayed until four or seven days postpartum, compared to one day (Stěhulová et al., 2008), and this effect is prolonged and further intensified when the animals have visual and auditory contact after separation. On the 
other hand, delayed separation influences the later social behaviour of calves in a way that may enhance their coping abilities (Bouissou et al., 2001). Johnsen et al. (2015a) found calves, separated from their mothers after eight weeks of suckling, to display less alert behaviour and high-pitch vocalizations if they were separated with a fence allowing physical contact, compared with a solid wall allowing merely auditory contact. Maternal rearing during four days and group housing, as compared to rearing without dam and individual housing, respectively, independently increase growth and play behaviour in dairy calves (Valníčková et al., 2015). Group housing has also been shown to improve cognitive performance (Gaillard et al., 2014).

Group pens equipped with automated milk feeding systems are commonly used for heifer calves to reduce labour and enable delivery of milk at volumes and frequencies that are more natural and support fast growth (Fig. 5). Additionally, the automated calf feeder gives each calf more space, allows social interaction between calves and generates data on individual milk intake which can be used to monitor calf health (Borderas et al., 2009). However, the system can increase the risk of clinical respiratory-tract disease and even reduce growth rate (Svensson et al., 2003, 2006). Stable groups of no more than eight calves seem preferable from an animal health perspective (Svensson and Liberg, 2006; Engelbrecht Pedersen et al., 2009). As pointed out by Barkema et al. (2015), it may be difficult to achieve small and stable calf groups in practice, especially at small farms. Further research on the management of this rearing system is, therefore, needed.

Vasseur et al. (2010a) studied calf management practices and welfare in Canada and identified the following factors as causing major risks: no access to a calving pen and poor surveillance of calvings, especially at night; no disinfection of newborn's navel and delayed identification and monitoring of calf; unreliable feeding of colostrum of unknown quality; dehorning and removal of supernumerary teats at a high age and without adequate pain management; restrictive milk feeding and feeding with waste milk without precaution; abrupt weaning and inappropriate housing (i.e. in crate, tied or attached against a wall).

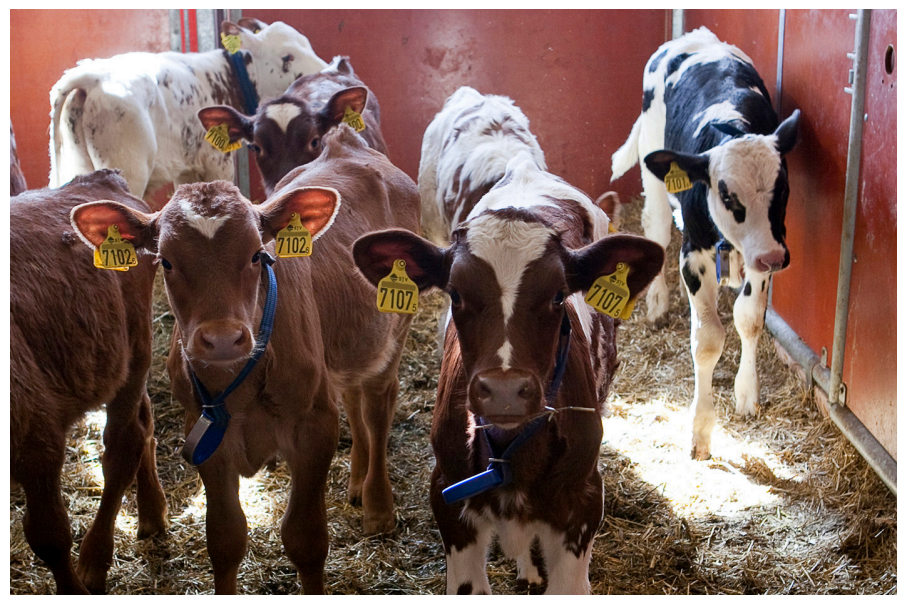

Figure 5 Calves are typically separated from their mothers shortly after birth, and from one week of age reared in groups with automatic milk feeders (Photo: J. Svennås-Gillner, Swedish University of Agricultural Sciences). 


\subsection{Painful and frightening procedures}

Pain, fear and distress are obvious welfare issues in dairy cattle, although their relative importance is contentious. A number of surgical mutilations are performed routinely in dairy calves. Castration and disbudding cause pain and subsequent stress to calves (Anon., 2014a). It is now clear that a combination of sedation, a local anaesthetic and a nonsteroidal anti-inflammatory drug is needed to reduce the pain during these procedures and afterwards (Fig. 4; Stafford and Mellor, 2005; Stock et al., 2013; Anon., 2014a).

It is less well known how age influences the effect of pain on welfare. Mutilations usually require animals to be restrained, which in itself may cause distress, in addition to the pain from surgery. Less force is needed to restrain a small animal, which may imply a lower stress response at young age. The tissue damage will also be more limited in young animals, possibly resulting in less pain. On the other hand, because of the immaturity of the nociceptive system, young animals might be more sensitive to pain (Loizzo et al., 2009). For necessary mutilations, research is needed to find the optimal age.

Castration of male dairy calves destined for meat production is one of the most common management practices performed in intensive milk production. It is usually achieved by surgical removal or physical damage to the testicles. In most countries male dairy calves are castrated to facilitate handling during rearing for meat production. The extent to which analgesic treatment is applied varies greatly.

It is generally recommended that intensively kept loose-housed adult dairy cattle be dehorned to prevent injuries in animals and staff and facilitate animal handling. Heifer calves are usually disbudded at the age of 4-8 weeks, when horn buds are 5-10 mm long, using a heated disbudding iron or caustic paste. In a survey in 2007, the US Department of Agriculture reported $94 \%$ of the dairy operations to routinely dehorn their heifer calves and $18 \%$ to use analgesics (Anon., 2009b). According to a European survey in 2009, $82 \%$ of the dairy cattle in Europe were dehorned, most commonly by disbudding, and only $20 \%$ of the herds used analgesics, with considerable variation between countries (Anon., 2009a). Optionally, there are some prospects for genetic selection for polledness (Medugorac et al., 2012).

Another common practice is to remove supernumerary teats in replacement heifers. Such extra teats can affect normal milking and may get infected, thus contributing to reduced welfare (Anon., 2009d). The United States Department of Agriculture (USDA) reported $50 \%$ of surveyed dairy operations in the United States in 2007 to remove extra teats routinely, usually during the first six months of life (Anon., 2009b). The animal welfare implications of this procedure are largely unknown.

Tail docking of cows was initially introduced to reduce the incidence of leptospirosis in milking personnel in New Zealand (Anon., 2014b), a causal link which was later refuted. According to the previously mentioned USDA survey, 39\% of the cows at dairy operation in the United States were tail docked in 2007, which was most commonly achieved by applying a band around the tail (Anon., 2009b). Research has shown that tail docking provides no advantages to the cows in terms of cleanliness or udder health (Sutherland and Tucker, 2011). Instead, it causes acute and chronic pain, as well as a reduced ability to use the tail, for example, to chase insects and in social signalling. Tail docking is banned or discouraged in most industrialized countries except the United States. EFSA has recognized tail docking as an important animal welfare issue (Anon., 2009d).

Since a couple of decades it has become an increasingly common practice in some regions to provide the newborn calf with the necessary colostrum through an oesophageal 
tube feeder. While a sufficient provision of high-quality colostrum is essential for calf health, the routine use of an oesophageal tube is questionable. Tube feeding requires restraint, and inappropriate handling of the feeder can cause severe injury to the animal.

\subsection{Transport and slaughter}

Animals of beef breeds constitute the main part of cattle slaughtered for meat production, and much focus is, therefore, on the transport and slaughter of these animals. However, sooner or later, most dairy cattle are also slaughtered. During loading, transport, unloading and while waiting to be slaughtered, the animals are subjected to multifarious challenges, including increased and rough handling, various unfamiliar sensations, loading onto and unloading from truck, uncomfortable lairage, deprivation of feed and water, poor climatic conditions and demanding social interactions due to separation, mixing of unfamiliar animals and crowding (Terlouw et al., 2008). The World Organisation for Animal Health (OIE) (Anon., 2016j) has recognized the significance of transport conditions for animal welfare.

Major welfare issues in slaughter are inappropriate handling facilities, rough handling and insufficient or non-existent stunning (Grandin, 2013). Research has shown that animal protection standards at commercial slaughter varies considerably and is sometimes unacceptably low (von Wenzlawowicz et al., 2012; Atkinson et al., 2013). Driving, restraint and stunning procedures are not always performed correctly, and operator competence is crucial. Old and inappropriate facilities for driving and handling the animals are common, leading to unnecessary rough human-animal interactions and stress in both abattoir personnel and cattle. In some abattoirs, electric prods are used extensively. Hemsworth et al. (2011) and Hultgren et al. (2014) found cattle stress reactions to be associated with rough handling at the abattoir. Atkinson et al. (2013) evaluated stun quality following stunning with a cartridge-driven penetrating captive bolt gun, and found signs of consciousness indicative of inadequate stun in $6.5 \%$ of the cows, steers and calves, and in $17 \%$ of the bulls.

A particularly controversial issue is slaughter without previous stunning for religious purposes. Stunning is performed to induce immediate unconsciousness, in that way ensuring slaughter without causing the animals any avoidable pain or distress. Stunning before slaughter is a statutory requirement in the European Union (Council Regulation [EC] 1099/2009), but exemptions from stunning are granted for religious groups. However, pre-slaughter stunning is accepted by some Islamic authorities, and in a few countries like Sweden, Denmark, Norway, Iceland, Switzerland, Liechtenstein and New Zealand, religious slaughter is allowed only after proper stunning.

Gregory et al. (2012) estimated that $10 \%$ or more cattle develop complications during bleeding at halal and shechita slaughter without stunning, taking longer to lose consciousness due to false aneurysms which develop in the arteries and stop the blood flow from the severed vessels, and continued blood flow to the brain through collateral routes. The time from cutting to final collapse exceeded 4 minutes in $1.5 \%$ of studied animals (Gregory et al., 2012). In connection with slaughter without prior stunning, cattle are frequently heavily restrained and sometimes turned on their side or back in order to expose the throat to the operator, thus inducing additional stress (Velarde et al., 2014). EFSA (Anon., 2004) concluded that there are serious welfare concerns with slaughter without stunning, and recommended that all slaughtered animals be adequately stunned in a humane way. 
In Europe, halal meat (following Muslim practice) is produced in much greater quantities than kosher meat (Jewish shechita slaughter). According to a survey among authorities and slaughter plants in different countries, the percentage of cattle (beef and milk breeds) slaughtered as halal was between 4.5 and $20 \%$ in Germany, Italy, Spain, Australia and Israel (Velarde et al., 2010). In Israel, 84\% were slaughtered according to shechita, while these animals constituted less than $1 \%$ in the remaining countries studied. In Belgium, France, Italy, Israel and Turkey, most or all slaughter plants performed halal slaughter without stunning, while German, UK and Australia abattoirs in most cases applied stunning before sticking. Production volumes of halal and kosher meat indicate that a large part is sold to the general public without being labelled as such.

In some countries, there is a market for cull cows for the purpose of fattening and meat production. Animals in a very poor condition may change hands repeatedly and spend considerable time in provisional facilities waiting to be sold and reloaded, which causes unnecessary stress and suffering.

\subsection{Poor stockmanship}

Humans inevitably play an important role in the life of dairy cattle, through both the control they exert over the animal environment and their physical presence (Waiblinger et al., 2006). Pre-industrialization literature giving advice on animal husbandry often emphasized the importance of gentle handling. A good relationship between cattle and humans reduces stress to routine management practices (Lensink et al., 2001; Waiblinger et al., 2004). Lürzel et al. (2015) found that gentle interaction was effective in reducing the calves' fear of humans. A negative human-animal relationship, indicative of fear and avoidance of humans, increases the risk for lameness (Chesterton et al., 1989; Rouha-Mülleder et al., 2009). However, in intensive dairy farming, close positive contact between farmer and animals is not always possible. Thus, human-animal relationships show a wide variation, from what can be termed close friendship (at least for the human's part), to a distanced approached focused on production efficiency and economic returns.

Whether the welfare of dairy cattle gets better or worse when herd sizes increase is somewhat controversial. Herd size is closely linked to a multitude of other environmental and management factors, such as housing system, feeding, milking and personnel, which makes it a difficult research task to distinguish the effect of herd size itself. It seems plausible that the level of animal care is lower in very small and very large units, because the stockperson has either too little specific competence or too little time for each animal (Waiblinger and Menke, 1999). The authors found some correlation between herd size and the human-cow relationship, but the personality and attitudes of the stockperson were more important determinants of good human-animal relationship. There is some evidence that calf mortality tends to increase with increasing herd size (Gulliksen et al., 2009).

In large herds, there are often several milkers and personnel changes occur more often (Menke et al., 1999). Human-animal interaction is common in connection with traditional milking, but in automatic milking systems this way of contact is largely broken. Due to low personal stakes and a lack of commitment, employees at corporate dairies may go about their work less carefully than family-farm managers (Uetake, 2013). On the other hand, large dairies may be able to invest in facilities and technologies for animal monitoring (Svensson and Jensen, 2007; Borderas et al., 2009; Rutten et al., 2013; Chanvallon et al., 
2014), education of staff (Schuenemann et al., 2013), advisory tools (Vasseur et al., 2010b) and special herd health services.

Dairy cattle can to some extent recognize humans and respond negatively to the presence of aversive handlers during milking, resulting in behavioural reactions and reduced milk yield (reviewed by Rushen et al., 1999). Appropriate strategies to recruit and train stockpeople are important in safeguarding the welfare of dairy cattle, because the behaviour of handlers can have large motivational and emotional effects on the animals (Hemsworth, 2009). Hemsworth (2003) suggested that cognitive-behavioural training programmes for stockpeople be introduced in the livestock sector.

\section{Husbandry practices in dairy farming: health, productivity and breeding}

\subsection{High milk yield}

Animal welfare is sometimes portrayed (by industry spokesmen) as a prerequisite for high milk yields, or (by animal welfare advocates) as being in conflict with animal production. Neither is completely true. In general, welfare can be expected to increase with productivity up to a maximum, and to successively drop with a further increase in productivity beyond this point (Mclnerney, 2002; Edwards, 2008), as roughly illustrated by Fig. 6, although the details of this relationship are likely to depend on the chosen welfare definition.

Genetic selection has contributed significantly to increased milk yields. It has been estimated that about half of the increase in yield during recent decades is attributable to

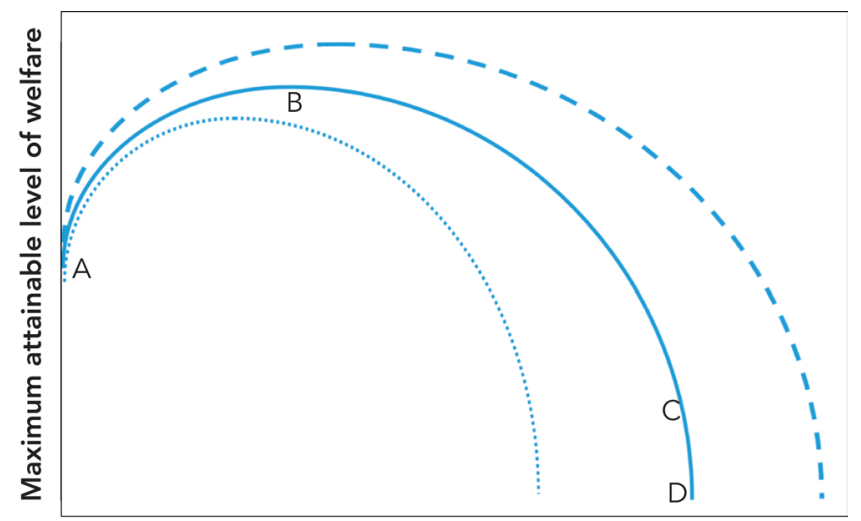

Productivity

Figure 6 Theoretical model of the conflict of interest between animal welfare and productivity (solid line). A given position on the curve represents a trade-off between maximum attainable welfare and productivity. Without producing, the animal can reach a certain level of welfare (A) If productivity increases, maximum attainable welfare improves up to a certain point (B). With further increase of productivity, welfare drops down to an unacceptable level (C) until the animal finally dies (D) Genetic progress or changes in husbandry can alter the model, resulting in improved (dashed line) or deteriorated (dotted line) welfare and/or productivity (modified from Mclnerney, 2002; Edwards, 2008). 
genetic progress, and the rest comes from improved management and feeding (Pryce and Veerkamp, 2001; VanRaden, 2004).

Animals in a population that have been selected for high productivity appear to run a higher risk of behavioural, physiological and immunological problems, leading to impaired animal welfare (Rauw et al., 1998; Anon., 2009c). In high-producing cows, metabolic stress resulting from excessive tissue mobilization in early lactation (Bauman and Currie, 1980; Oltenacu and Broom, 2010) is thought to contribute to poor welfare. High-producing cows need to spend more time eating and might have less time available for other activities, such as resting. It is likely that such cows are more dependent on good management and feeding, including grain-based diets which may, in turn, be negative for cow welfare. Finally, continued increase in production may be perceived by the public as unethical and undermine consumer trust, on which the dairy industry relies.

In the United States and a number of other countries, recombinant (artificial) bovine somatotrophin is used to enhance milk production in dairy cows. Research has shown that this treatment results in a $25 \%$ increase in the risk of clinical mastitis, a $40 \%$ reduction in conception rate and 55\% increased risk of clinical lameness (Dohoo et al., 2003). The use of recombinant bovine somatotrophin in dairy cattle is not allowed in Canada, Australia, New Zealand, Japan, Israel and the European Union.

Culling is the departure of cows from the herd due to sale, slaughter or death. On an average, intensively fed high-producing cows are not retained in the herd for very long and many are culled before the end of their first lactation. It is not uncommon that 38-40\% of all cows calving in a herd are heifers that substitute older cows being culled. Overall, the most common reasons for voluntary culling are reproductive failure, mastitis and low production (Bascom and Young, 1998; Ahlman et al., 2011). An overall high culling rate suggests that the animals have been pushed beyond what is biologically sustainable into a state that is opposed to good welfare (Mellor et al., 2009), and a decreased length of productive life of dairy cows due to involuntary culling because of reproductive failure, illness, injury or death is a major animal welfare and ethical issue.

\subsection{Breeding goals and reproductive management practices}

Increased milk production, which has been the main aim of breeding of dairy cattle for the last half a century, and systematic genetic selection for a high yield, generally practised since the 1990s, have led to problems for several reasons. Increased yields have resulted in declining reproduction and longevity (Rodríguez-Martínez et al., 2008; Oltenacu and Broom, 2010). There is substantial unfavourable genetic correlation of milk yield with fertility (Veerkamp et al., 2003), indicating that further one-sided selection will aggravate this problem.

In order to cope with declining fertility and rationalization, dairy farmers apply intensive reproductive management of the cows. Most cows are either inseminated at spontaneous oestrus or inseminated after bi-weekly injections of prostaglandin, in both cases requiring the stockman to detect cows in oestrus. Additionally, so-called timed artificial insemination is used to eliminate oestrus detection. The standard protocol involves repeated injections of gonadotropin-releasing hormone and prostaglandin followed by insemination after ten days (Bisinotto et al., 2014). However, pregnancy rates are often low, which requires complementary oestrus detection. Detection aids like tail paint, pressure devices or pedometers are common but require additional management and attention. 
According to a survey conducted in the United States in 2007, 55\% of the dairy operations inseminated most of their cows to spontaneous oestrus at first service $157 \%$ for heifers), and 22\% used some kind of hormonal oestrus synchronization of most cows (7\% for heifers), while 22\% (for cows) and 33\% (for heifers) used natural service by a bull (Anon., 2009b). In later services, synchronization was more common, and more than one-half of the operations used protocols for Al synchronization for at least some cows during one year. Oestrous synchronization is also common in New Zealand (Burke and Verkerk, 2010). Intensive reproductive management has ethical implications, and hormonal residues may pose a risk to consumers of animal products. The European Union does not allow the use of drugs with oestrogenic or gestagenic action for reproductive management in dairy cattle.

An additional consequence of genetic selection for milk production is a decreased economic value of bull calves of dairy breed. Sexed semen can be used to reduce the number of unwanted dairy bull calves. Based on epidemiological data on clinical diseases, reproductive performance and culling in Swedish primiparous cows, presented by Oltenacu et al. (1990), Anon. (2012a) calculated the combined animal welfare effect of sexed semen, and concluded that it improves the welfare of the cows. The major benefit $(76 \%)$ is associated with elimination of unwanted male calves, and additional benefits come from a lower frequency of diseases. Sexed semen might be perceived as unethical by the public.

\subsection{Diseases}

Prevention and control of health disorders are widely recognized as fundamental to animal welfare. Such practices can contribute to animal welfare by a combination of hygiene, vaccination and anti-parasite treatments; by biosecurity measures to prevent the entry of specific pathogens into farms; by management routines to limit spread of disease within farms and by eradication programmes to eliminate certain diseases within countries or other regions (Fraser et al., 2013).

Most researchers regard leg and hoof disorders, udder disease and metabolic disorders as major animal welfare issues (Anon., 2009d). Leg and hoof diseases are common and often painful, causing lameness of a prolonged course (Fig. 7). It is not uncommon that hoof lesions remain undetected, and thus untreated (Van Nuffel et al., 2015). Likewise, clinical and acute mastitis is common and often painful, although the clinical phase is more likely to be of short duration (Medrano-Galarza et al., 2012). Painful conditions can, if not dealt with properly, lead to severe undernutrition.

A number of scientific studies have shown that both mastitis resistance and the clinical manifestation of ketosis, ovarian cyst, mastitis and lameness are genetically correlated with high milk yields (reviewed by Ingvartsen et al., 2003), indicating that continued selection for higher milk yield will increase the incidence of these diseases. The incidence of production-related diseases has increased greatly over the last decades. For example, Clarkson et al. (1996) estimated the prevalence of lameness in Welsh dairy herds to be $21 \%$, while more recent prevalence estimates were $37 \%$ in English and Welsh herds (Barker et al., 2010) and 39\% in zero-grazing UK herds (Haskell et al., 2006).

New threats emerge from vectors spreading to previously unaffected regions due to climatic changes, such as biting midges (Culicoides spp.) that propagate the bluetongue and Schmallenberg viruses (Beer et al., 2013; Zuliani et al., 2015). 


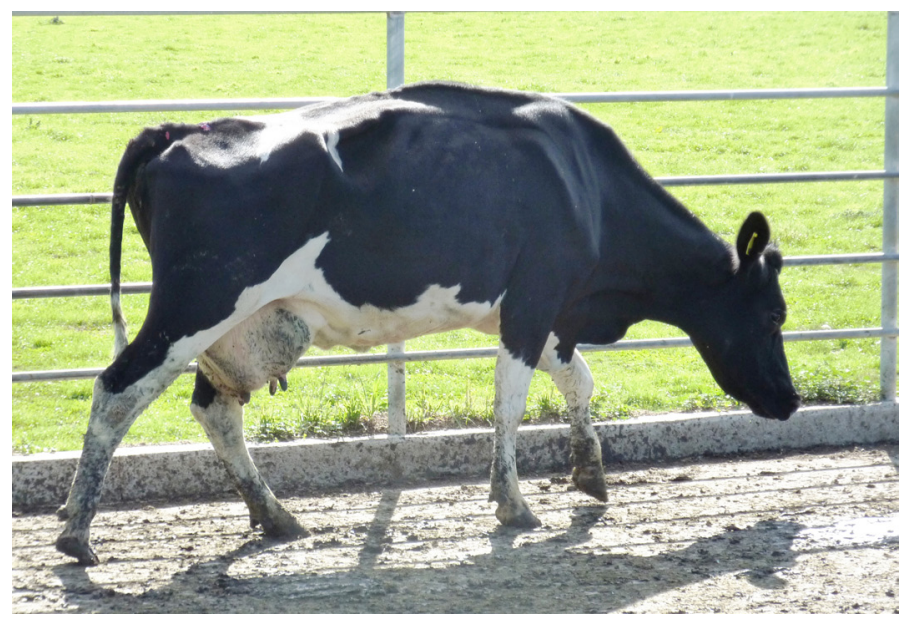

Figure 7 Hoof disorders are extremely common in dairy cows and cause pain and impaired locomotion. They are multifactorial diseases caused by poor housing, management and feeding, as well as specific pathogens. Unilateral genetic selection for high milk yields increases cow susceptibility (Photo: C. Bergsten, Swedish University of Agricultural Sciences).

Antimicrobial resistance is a rapidly growing public and animal health threat of broad concern (Anon., 2016a,b,c). Although the causes of antimicrobial resistance are complex, liberal use of antibiotics contributes by being a main driver of selection pressure (Grave et al., 2012; Laxminarayan et al., 2013). Most of the antibiotics manufactured goes to agriculture, horticulture and veterinary medicine (Laxminarayan et al., 2013). The use of antibiotic growth promoters is banned in the European Union.

\section{Applying different perspectives on animal welfare to the case of dairy farming}

\subsection{Increasing awareness of animal welfare issues}

After the Second World War, some people began to worry about the consequences of the intensification of milk production. Early public concerns about how animals were raised and treated were articulated by ethicists and social critics, such as the British animal welfare advocate and author Ruth Harrison in her seminal work Animal Machines (Harrison, 1964). It alerted the public to the fact that the industry regarded farm animals merely as production objects. Harrison described the continuous effort to obtain ever-greater production profits at whatever cost to the animals. The book had a profound impact on public opinion and agriculture, not only in the United Kingdom. It revealed farm practices such as castration and de-horning without analgesia, and feed antibiotics to people who were largely ignorant of such practices. Other animal welfare advocates, ethicists and philosophers were to follow. 
In a wider perspective, the changes in agriculture and milk farming seen in the last century have had both positive and negative effects on animal welfare (Fraser, 2001; Mellor et al., 2009). Nonetheless, despite obvious progress in production efficiency, the overall positive effects of intensive milk production on animal welfare are rightly questioned.

Our ideas of what is best for the animals are affected by what we know - or rather think we know - about their minds and needs, and by respect for the animals. Keeping animals under conditions that appear unnatural, in which they cannot perform many of their innate behaviours or fulfil their basic biological needs, raises valid concerns about how to understand animal welfare. For cattle, natural life is generally thought to involve grazing on range land, with natural mating and young calves suckling from their mothers. This contrasts with the conditions under which dairy cattle are usually managed in intensive production systems, which many informed citizens find deeply unsatisfactory.

Although there is broad consensus that farm animals are sentient beings and that good treatment and care are important for keeping them healthy and in good shape, there are diverging views on the minimum acceptable level of welfare, that is, what level ought to be provided. This question does not lend itself easily to objective assessments and judgements, because it has to do both with the definition of animal welfare we choose to adopt and how different values should be weighed against each other (Tannenbaum, 1991; Fraser, 2008a; Appleby et al., 2014). Most scientists agree that animal welfare should be defined in terms of biological functioning (e.g. health), emotional state and natural living (Fraser, 1999, 2008a). However, priority between these three aspects varies quite a bit. Moreover, despite considerable research efforts, there is a great deal of uncertainty regarding the effects of certain husbandry conditions and practices on animal welfare.

In the quest for valid principles and a standard procedure for assessing animal welfare, many attempts have been made to design assessment protocols, for dairy cattle as well as other animals. Through a massive scientific effort, the Welfare Quality ${ }^{\circledR}$ project (Blokhuis et al., 2013) developed and tested a system for providing a standard way of converting science-based welfare measures into relevant consumer information. After extensive discussion with consumers, representatives of key stakeholder groups, policymakers and scientists, it was decided to base the system on the four main principles 'good feeding', 'good housing', 'good health' and 'appropriate behaviour' (Blokhuis et al., 2008). Within these principles 12 distinct and complementary welfare criteria were highlighted. Finally, measures useful for the assessment of the principles in practice were identified, designed and tested, resulting in assessment protocols for different species, including cattle (Anon., 2009e). Notable was the focus on welfare measures taken on animals, the so-called 'animal-based measures' or 'output measures'.

Since published, the Welfare Quality ${ }^{\circledR}$ principles, criteria and protocols have almost become regarded as the 'truth' of animal welfare. This is presumably due to the pressing need for valid welfare assessment standards and great confidence in the scientific approach chosen by the project. However, for reasons related to education, time constraints and data analysis, the complete protocols have proven difficult to apply on a large scale in practice. Further research is needed to develop less comprehensive but sufficiently accurate protocols. Several initiatives have been taken in this direction (Bracke et al., 1999; Andreasen et al., 2014). As an alternative approach, several systems have been designed for measuring the welfare of dairy cattle exclusively at herd level. However, such systems would not be strictly in line with the intentions of legislation that sets minimum acceptable conditions for every individual animal (Lundmark et al., 2015). 


\subsection{Naturalness and the positivist heritage}

Because the idea of natural behaviour has proved appealing, also in animal welfare legislation, researchers have attempted to grasp and accommodate it conceptually (Thorpe, 1965; Bracke and Hopster, 2006; Lund, 2006). The notion of something essentially important for an animal of a given species - at its present level of domestication and breeding - may be relevant. Unfortunately, it is somewhat troublesome to apply the concept of natural behaviour to animals that have changed their behavioural repertoire through many generations of breeding, such as cattle bred for high milk production (Jensen, 2006; Anon., 2009d). A behaviour might not qualify natural just because it occurs often in a large percentage of animals, occurs under unconfined conditions, satisfies a strong intrinsic drive or results from genetic adaptation with no direct human interference.

Algers (1992) suggested that a behaviour is natural if the animal is strongly motivated to perform it and, when performing it, receives functional feedback. According to Algers, functional feedback should be understood as interaction with the environment in a way determined by genes and previous experience. This adheres well to Aristotelian ethics, in which an animal should be able to live and develop according to its telos (purpose or function for which it was biologically evolved). This logic seems to fit well with the public request for naturalness in animal production; that animals should be able to behave naturally, but also that there should be natural elements in their environment.

Since long it has been argued that the natural sciences and the humanities constitute separate cultural realms with little mutual understanding and communication. However, neither empirical information nor ethical reflection alone can answer questions about our proper relationship with other species. The notion that subjective experience should not be included in scientific study stems from a strain of philosophy of science called positivism (Rollin, 1990), which attempted to separate science and metaphysics and claimed that we should not postulate unobservable processes to explain observable ones.

Tannenbaum (1991), Lund and Röcklinsberg (2001), Sandøe et al. (2003), Fraser (2008a) and others have recognized that animal ethics and animal welfare sciences are inherently linked to each other, and that ethicists and philosophers have important roles to play in animal welfare science. Tannenbaum argued that normative choices should be made explicit, that goodness is the central evaluative concept in animal welfare and that philosophers can help scientists in the evaluation. More recently, the combination of animal welfare science and ethics has gained recognition and attracted growing interest internationally, as reflected in the names of scientific institutions, courses and government bodies. It has been suggested that animal welfare and animal ethics should be taught together in agricultural and veterinary education (Edwards, 2002; Hanlon, 2008), and an increasing number of institutions provide education in animal welfare science, ethics and law (Main et al., 2005; Broom, 2010).

The dualistic view separating ethics and science is, however, still influential. Scientists often adopt a minimalistic strategy, relating animal welfare to more easily measured states, such as health or behaviour, thus avoiding elusive and possibly controversial manifestations of poor welfare like negative emotions or lack of integrity (Rollin, 1995). This may be a problematic position because, if values that the public regard as central to animal welfare are highly disregarded, it may undermine public trust in expert judgement and opinion (Fraser et al., 1997). Furthermore, by avoiding and excluding some manifestations of poor welfare, researchers may, in fact, overestimate welfare (Verhoog, 2000). 


\subsection{Differing perceptions of animal welfare among citizens and stakeholders}

In light of the idea that there is no simple truth about the nature of animal welfare, nor about which issues are most relevant to consider, it may be intuitively appealing to include subjective attitudes and opinions in the discussion. By asking people about their perceptions of animal welfare and what they think are acceptable, poor or excellent animal welfare conditions, it may be possible to get a comprehensive view of the most common views among a broad spectrum of citizens and stakeholders.

Roex and Miele (2005) recognized that the view on animals and animal welfare varies between different groups of European producers, retailers and consumers. While producers tend to draw mainly on scientific understandings and consider animal health, consumers have some humanistic preferences and tend to give the animals a status as subjects, and animal rights advocates have an almost purely humanistic understanding. This research revealed a widespread perception in stakeholders that confined systems of production are inherently detrimental to the welfare of farm animals, but also that stakeholders overall lack knowledge of contemporary farming practices. Other researchers have found that veterinarians and farmers generally tend to relate animal welfare to health, while citizens relate more to natural behaviour (Vanhonacker et al., 2008).

A number of studies have shown a great concern for animal welfare issues among the citizens in many industrialized countries. Eurobarometers and other surveys have shown that a high percentage of European and North American citizens see animal welfare as an important issue, and that they have worries about the welfare of farm animals (Zogby, 2003; Anon., 2015c, 2016d; Schuppli et al., 2014).

Forty-four per cent of surveyed adult consumers in the United States said they wanted to know more about how food companies treat the animals used in their products (Anon., 2015c). About the same percentage (47\%) said they supported companies that avoid inhumane treatment of animals. In addition, almost two-thirds indicated that they wanted animals raised in as natural an environment as possible.

Lusk and Norwood (2008) found that a majority (56\%) of respondents in randomly chosen households of the United States believed decisions about farm animal welfare should be made by experts rather than being based on the views of the public, and that decisions should rest on scientific measures of animal well-being, as opposed to moral and ethical considerations. Interestingly, respondents who believed farm animal welfare decisions should be made by experts and be based on scientific measures were the least concerned about farm animal welfare issues.

Farming experience and value orientation appear to influence attitudes and preferences regarding milk production. Dutch citizens with experience or knowledge of farming (through visits, work or rural residency) have been found to be more satisfied with contemporary dairy farming, more accepting of modern husbandry practices and more willing to pay for added values than those who had less experience or knowledge (Boogaard et al., 2011).

The public views on animal welfare in the so-called emerging economies of Asia and Latin America are of special interest. Despite the fact that China counts with the largest dairies and is one of the largest producers of bovine milk in the world (Anon., 2016f), animal welfare in China is, in effect, still in its infancy. You et al. (2014) investigated public 
attitudes to animal welfare in China, with a focus on pigs and fowls. Two-thirds of the respondents had never heard of animal welfare. However, almost three-fourths claimed that, for the sake of food safety, the rearing conditions should be improved.

\section{Recommendations for improving animal welfare in dairy farming in the light of expected future developments}

\subsection{Continued intensification}

With the present pace of development of the dairy sector in the industrialized world, we should expect continued intensification with fewer and larger dairy farms, increased milk yields, increased automation of herd management, continued internationalization of milk processor companies and dairy product trade, shrinking profit margins of milk farmers and further production cost cuts. Unfortunately, a unilateral focus on intensified milk production, which by some is considered the best way forward, is likely to aggravate many animal welfare problems.

The urge for further intensification ignores the fact that many citizens tend to reject industrial animal production, at least partly attributing this to reduced animal welfare (Hardeman and Jochemsen, 2012; Hötzel, 2014). Consumer demand for cheap, safe and ethically sound milk products will continue, creating incentives for quality assurance based on efforts for sustained or improved animal welfare, as well as biosecurity, limited drug use, reduced environmental impact and a desirable agricultural landscape. A great deal of research is likely to be directed at dealing with the multitude of potential conflicts of interests that follow from the aspirations for sustainability.

To achieve significant improvements in the welfare of dairy cattle and thus sustainable milk production, we need to envisage arrangements that allow us to predict, assess and communicate the consequences of remedial actions at all levels of the food chain, and policies that permit efficient and ethically acceptable milk production systems to flourish. The future successful milk farmer will be most likely skilled in animal and staff management, scientifically knowledgeable, with a professional ethic of animal care and a great understanding of the need to conform to legislation, standards and societal expectations. Below, a number of prioritized areas are indicated, where further research and remedial actions are required.

\subsection{Prioritized areas}

The most effective route to stop the decline of animal welfare caused by unilateral genetic selection for high milk yield is by adopting a selection index in which welfare-related traits such as health, fertility and longevity are included and appropriately weighted (RodríguezMartínez et al., 2008; Anon., 2009d). Already in 1997, the United Kingdom's Farm Animal Welfare Council stressed the paramount importance of good welfare in breeding programmes, and recommended that 'breeding companies should devote their efforts primarily to selection for health traits so as to reduce current levels of lameness, mastitis and infertility' (Anon., 1997). 
A global and multi-sector system for surveillance of antibiotic use and antimicrobial resistance is urgently needed (Anon., 2016a,b,c), as a first step towards limiting imprudent use of antibiotics that will potentially threaten future animal health care and welfare. The use of hormones in dairy cattle should be limited to therapeutic contexts.

Research and surveillance is needed to reveal animal health risks associated with ongoing climate change, for example, through spread of disease vectors to new regions. Whenever possible, dairy cattle should be allowed access to pasture.

Rearing together with the dam can provide health and welfare benefits for the calf (Krohn, 2001; Flower and Weary, 2003). Cow and calf response to separation increases when the calf spends more time with the dam, but there may be long-term benefits of prolonged contact in terms of sociality, fearfulness, health and future maternal behaviour. Research is needed in order to develop functional dairy management systems that respect the natural social behaviour of cows and calves during the calf-rearing period (Johnsen et al., 2016). There is also a need to address ways to control transmissible diseases when dairy cattle are kept in mixed age groups.

In general, mutilations should be avoided. Routine tail docking should not be allowed. When performed, painful procedures such as castration and disbudding should be accompanied by sedation, local anaesthesia and post-operative anti-inflammatory treatment. Research is needed to elucidate the effects of painful procedures on calves of different ages.

The susceptibility of cattle to challenges during potentially demanding conditions like restraint, transport and slaughter depend to a great extent on the animals' previous experiences. Gentle interaction with humans early in life and training of cattle for future restraint and human handling can reduce animal stress (Grandin, 1998; Probst et al., 2012). Animal handling can be improved through vocational education and training programmes aimed at improving attitudes and behaviour of handlers towards their animals (Hemsworth et al., 2002).

A relatively new area of great potential is precision dairy farming, which is the use of technologies to measure physiological, behavioural and production indicators on individual animals to improve management strategies and farm performance (Bewley, 2010). Precision dairy management technologies provide great opportunities for improvements in individual animal management on milk farms (Bewley et al., 2015).

Cow-level recordings from automated feeding systems for calves and cows, automatic milking systems, devices relying on the global positioning system, pedometry and biotelemetry result in huge amounts of data, so far used only in a very small degree. Automatic monitoring equipment is already developed and will be used increasingly to record milk yield and composition, body temperature and activity in order to identify cows in oestrus, cows that are about to calve, lame cows, mastitic cows and fresh cows that are off feed. New technical solutions will probably be developed to continuously monitor heart and respiration rates, chewing activity, gas emissions and to detect rumen dysfunction and deviations in body condition (Fig. 8).

Animal transportation should be reduced. Network analysis has shown that strategic planning of cattle slaughter transports in Sweden can reduce total transport distances by $40 \%$, without changing the choice of abattoir and slaughter capacity, and if all cattle were sent to the nearest plant, distances could be reduced by $60 \%$ (Håkansson, 2012). There are prospects for small-scale and mobile on-farm slaughter of cattle, which would eliminate or reduce transportation and potentially reduce pre-slaughter stress. In mobile slaughter, a self-contained unit housed in a road vehicle is taken to the farm, instead of 


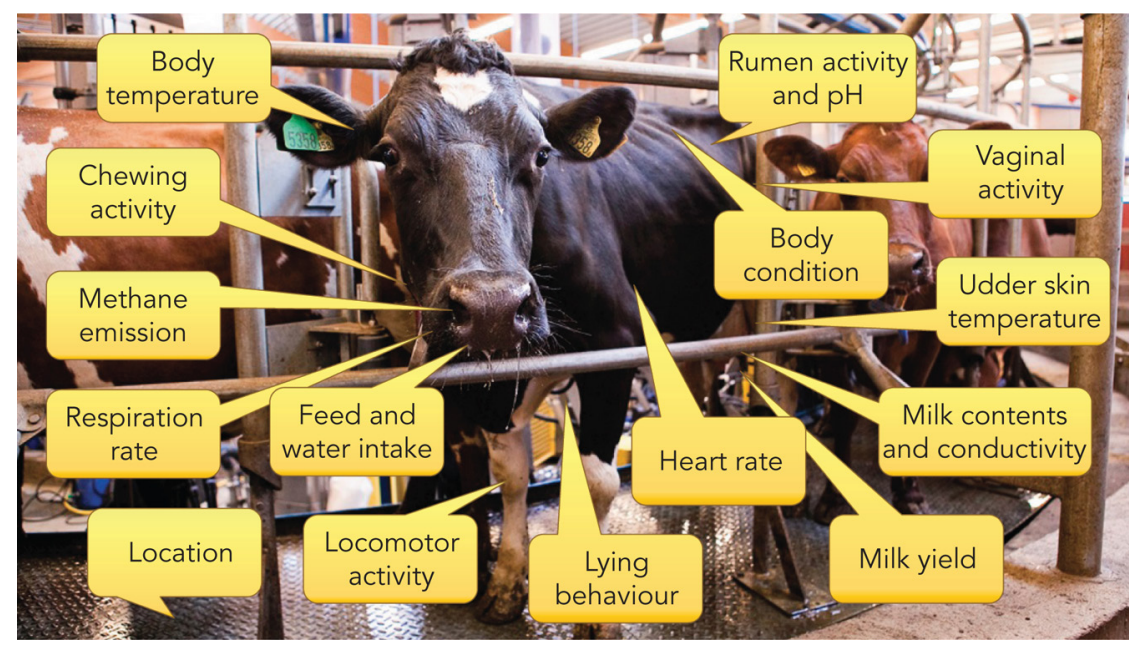

Figure 8 Presently or soon available measurements for automatic monitoring of cows to support precision dairy farming (Photo: J. Svennås-Gillner, Swedish University of Agricultural Sciences).

transporting the animals live to an abattoir. Håkansson (2012) found that small-scale and mobile slaughter would have only a limited effect on total transport distance but would cut the longest distances.

An efficient way to reduce stress in dairy cattle at large-scale abattoirs is to ensure that facilities and equipment for animal handling allow for smooth and effective forward movement of animals, and that handlers understand and respect the principles of good human-animal interaction (Grandin, 2013). Effective stunning methods should always be applied before sticking.

\subsection{Assessment and communication of animal welfare}

Development of practically useful methods for regular assessment of the level of animal welfare in dairy herds is needed (Anon., 2012b). To be credible, such methods must integrate all aspects of animal welfare relevant to the public, including respect for naturalness.

Risk assessment can be used to identify major risks for poor welfare (Anon., 1999; Algers, 2009; Paton et al., 2013), thus directing policies, prevention and official control. However, as discussed above, welfare determinants and manifestations are inherently complex, and currently used methods for risk assessment have several unresolved methodological limitations (reviewed by Müller-Graf et al., 2008; Smulders, 2009; Anon., 2010a), calling for alternative approaches. Further data on the effects of determinants of dairy cattle welfare are needed to reduce uncertainty and allow for quantitative risk assessment. Research is also needed to facilitate monitoring and surveillance of farm animal welfare risks at national and international levels, utilizing databases created for other purposes (Dewey et al., 2009; Houe et al., 2011; Nyman et al., 2011).

The consumption of specially labelled products and its role in improving the welfare of livestock have attracted considerable attention (Heerwagen et al., 2015). There is a diverse market for welfare-friendly products and services. Apart from legal regulation, 
voluntary welfare-based certification and assurance play an important role in promoting such products (Mellor and Bayvel, 2008; Mench, 2008; Veissier et al., 2008; KilBride et al., 2012; Heath et al., 2014).

It is essential that milk products be presented transparently and fairly, to limit the risk for ethical conflict and misunderstanding (Bunting and Galyean, 2015). Undue profit by wrongly presenting the products as 'natural' should be avoided in order not to mislead consumers and risk losing valuable confidence among citizens (Borkfelt et al., 2015). The ongoing intensification of milk production does not appear to address this issue sufficiently.

\section{Summary}

Despite obvious progress in production efficiency in the last century, the overall positive effects of intensive milk production on animal welfare are rightly questioned. A large number of factors influence the welfare of dairy cattle, not least husbandry conditions. The determinants and manifestations of animal welfare are inherently complex, which complicates proper assessment and communication of welfare issues.

Some areas for further research and action are identified. Genetic selection should include welfare-related traits. International surveillance of antibiotic use and resistance is urgent. Dairy management systems that respect the natural social behaviour of cattle should be developed. Mutilations should be avoided if possible and, if performed, accompanied by proper analgesic treatment. Facilities and equipment for animal handling should allow for smooth and effective movement of animals, and handlers need to understand and respect the principles of good human-animal interaction. At slaughter, effective stunning methods should always be applied before sticking.

The urge for further intensification ignores the fact that many citizens tend to reject industrial animal production, at least partly because of reduced animal welfare. Unfortunately, a unilateral focus on intensified milk production, which by some is considered the best way forward, is likely to aggravate many animal welfare problems. Significant improvements in the welfare of dairy cattle and thus sustainable milk production will require arrangements that allow prediction, assessment and communication of the consequences of remedial actions at all levels of the food chain, and policies that permit efficient and ethically acceptable milk production systems to flourish. The welfare of farm animals would improve if the gap between producers and consumers is bridged.

\section{Where to look for further information}

There is a rich flora of textbooks on dairy cattle welfare and related subjects. Examples that the reader may find useful are (in alphabetical order) Aland and Madec (2009), Appleby et al. (2011, 2014), Blokhuis et al. (2013), Broom (2014), Broom and Johnson (2000), Fraser (2008b), Gjerris et al. (2013), Haynes (2008), Hemsworth and Coleman (2011), Mellor et al. (2009), Rushen et al. (2008) and Webster (2005, 2011). Fraser et al. (2013) wrote a review to illustrate the broad range of science relevant to animal welfare and its application to animal welfare standards and practices, using OIE principles as a framework. Barkema et al. (2015) conducted an excellent review on contemporary issues specifically pertaining to the welfare of dairy cattle. 
Scientific work related to dairy cattle welfare is published in a large number of scientific journals, among which can be found (in alphabetical order) AMBIO, Animal, Animal Welfare, Anthrozoös, Applied Animal Behaviour Science, Journal of Animal Science, Journal of Dairy Science, Journal of Agricultural and Environmental Ethics, Livestock Science and PLOS ONE. Further journals can be identified by scrolling the reference list at the bottom of this chapter.

The OIE and the Food and Agricultural Organization of the United Nations (FAO) play prominent roles in animal welfare worldwide. In 2013, an OIE Regional Platform on animal welfare for Europe was formed, with the purpose to empower veterinary services to take action on animal welfare in compliance with OIE standards. In a special issue of its Scientific and Technical Review, OIE outlined contemporary thinking about factors that promote or jeopardize the productivity, health and welfare of the wide range of animals used for human purposes, including dairy cattle (Mellor and Bayvel, 2014).

The European region is leading in the development of animal welfare policies. Common animal welfare issues in the European Union are the responsibility of health and consumer issues Directorate General, the DG SANCO. The European Commission has websites dedicated to animal health, animal welfare and related educational efforts. EFSA undertakes scientific work on animal health and welfare through its Scientific Panel on Animal Health and Animal Welfare, mostly in response to requests from the commission. A European network of animal welfare reference centres has been considered and national centres exist in Denmark (DCAW), Finland (EHK) and Sweden (SCAW).

A large number of professional societies aim to promote a better understanding of animal welfare and the human-animal relationship, through scientific and educational activities. Examples are the International Society for Applied Ethology (ISAE), the Universities Federation for Animal Welfare (UFAW) and the European Society for Agricultural and Food Ethics (EurSafe). These societies organize international congresses every one or two years. Applied Animal Behaviour Science is the official journal of ISAE, and Animal Welfare is the official journal of UFAW.

In recent years, there have been a number of major EU-financed research initiatives. Notable examples are the Welfare Quality ${ }^{\circledR}$ project 2004-9, the Encouraging Dialogue on Issues of Religious Slaughter (DIALREL) project 2006-10, the European Animal Welfare Platform (EAWP) 2008-11, the Socio Economic Aspects of Farm Animal Welfare (EconWelfare) project 2008-11, the Alternatives to Castration and Dehorning (ALCASDE) project 2009, the Animal Welfare Indicators (AWIN) project starting in 2010, the Animal Welfare Research in an Enlarged Europe (AWARE) project 2011-14, the Animal Health and Welfare ERA-Net (ANIHWA) project 2012-15 and the EU project on the establishment of a coordinated European network for animal welfare (EUWelNet) 2013.

Examples of dairy cattle welfare research centres in the forefront are (in alphabetical order) Aarhus University, Denmark; Bristol University and Newcastle University, UK; the French National Institute of Agricultural Research (INRA), France; the Swedish University of Agricultural Sciences, Sweden; the University of British Columbia, Canada; and Wageningen University and Research Centre, the Netherlands.

\section{Acknowledgements}

I am extremely grateful for the willingness of researchers Helena Röcklinsberg, Lotta Berg and Stefan Gunnarsson at the Swedish University of Agricultural Sciences to review and 
comment on an early manuscript, and for enlightening and rewarding discussions with colleagues at the Department of Animal Environment and Health in Skara and Uppsala, Sweden over the years.

\section{References}

Ahlman, T., Berglund, B., Rydhmer, L. and Strandberg, E. (2011), Culling reasons in organic and conventional dairy herds and genotype by environment interaction for longevity, J. Dairy Sci., $94,1568-75$.

Aland A. and Madec, F. (2009), Sustainable Animal Production. The Challenges and Potential Developments for Professional Farming, Wageningen Academic Publishers, Wageningen, The Netherlands.

Algers, B. (1992), Natürliches Verhalten - ein natürlicher Begriff? Berliner und Münchener tierärztliche Wochenschrift, 105 (11), 372-4.

Algers, B. (2009), A risk assessment approach to animal welfare, in F. J. M. Smulders and B. Algers (eds), Welfare of Production Animals: Assessment and Management of Risks, Food safety assurance and veterinary public health, vol. 5, Wageningen Academic Publishers, Wageningen, The Netherlands, pp. 223-37.

Alvåsen, K., Roth, A., Jansson Mörk, M., Hallén Sandgren, C., Thomsen, P. T. and Emanuelson, U. (2014), Farm characteristics related to on-farm cow mortality in dairy herds: a questionnaire study, Animal, 1735-42.

Andreasen, S. N., Sandøe, P. and Forkman, B. (2014), Can animal-based welfare assessment be simplified? A comparison of the Welfare Quality ${ }^{\circledR}$ protocol for dairy cattle and the simpler and less time-consuming protocol developed by the Danish Cattle Federation, Anim. Welf., 23, $81-94$.

Anon. (1997), 'Report on the welfare of dairy cattle', Farm Animal Welfare Council, UK, http:// webarchive.nationalarchives.gov.uk/20121007104210/http://www.fawc.org.uk/reports/ dairycow/dcowrtoc.htm (accessed 26 February 2016).

Anon. (1999), 'Principles and guidelines for the conduct of microbiological risk assessment. CAC/GL 30-1999', Codex Alimentarius Commission, Food and Agriculture Organization of the United Nations, Rome, Italy and World Health Organization, Geneva, Switzerland, http://www.fao.org/ fao-who-codexalimentarius/standards/ (accessed 26 February 2016).

Anon. (2004), 'Opinion of the Scientific Panel on Animal Health and Welfare on a request from the Commission related to welfare aspects of the main systems of stunning and killing the main commercial species of animals', European Food Safety Authority, Parma, Italy, Report, http:// www.efsa.europa.eu/en/efsajournal/pub/45 (accessed 26 February 2016).

Anon. (2009a), 'ALCASDE - Final report, Study on the improved methods for animal-friendly production, in particular on alternatives to the castration of pigs and on alternatives to the dehorning of cattle', Institute of Agro-Food Research and Technology (IRTA), Girona, Spain, http://ec.europa.eu/food/animals/docs/aw_arch_alcasde_study_04122009_en.pdf (accessed 26 February 2016).

Anon. (2009b), 'Dairy 2007. Part IV: Reference of dairy cattle health and management practices in the United States 2007', United States Department of Agriculture, Fort Collins, USA, Report, https:// www.aphis.usda.gov/animal_health/nahms/dairy/downloads/dairy07/Dairy07_dr_PartIV.pdf (accessed 26 February 2016).

Anon. (2009c), 'Scientific opinion on the overall effects of farming systems on dairy cow welfare and disease', European Food Safety Authority, Parma, Italy, Report, EFSA J.I, 1143, 1-38, http:// www.efsa.europa.eu/en/efsajournal/pub/1143 (accessed 26 February 2016).

Anon. (2009d), 'Scientific report on the effects of farming systems on dairy cow welfare and disease', European Food Safety Authority, Parma, Italy, Report, Annex EFSA J., 1143, 1-284, http://www. efsa.europa.eu/en/efsajournal/pub/1143r (accessed 26 February 2016). 
Anon. (2009e), 'Welfare Quality ${ }^{\circledR}$ assessment protocol for cattle', Welfare Quality ${ }^{\circledR}$ Consortium, Lelystad, The Netherlands, Report, http://www.welfarequality.net/network/45848/7/0/40 (accessed 26 February 2016).

Anon. (2010a), 'Animal welfare risk assessment guidelines on housing and management (EFSA Housing Risk)', Wageningen UR Livestock Research, Wageningen, The Netherlands, Report, http://www.efsa.europa.eu/en/supporting/pub/87e (accessed 26 February 2016).

Anon. (2010c), 'Status and prospects for smallholder milk production. A global perspective', Food and Agriculture Organization of the United Nations, Rome, Italy, Report, http://www.fao.org/ docrep/012/i1522e/i1522e00.pdf (accessed 11 February 2016).

Anon. (2012a), 'Guidance on Risk Assessment for Animal Welfare', European Food Safety Authority, Parma, Italy, Report, EFSA J., 10, 2513, http://www.efsa.europa.eu/en/efsajournal/pub/2513 (accessed 26 February 2016).

Anon. (2012b), 'Scientific opinion on the use of animal-based measures to assess welfare of dairy cows', European Food Safety Authority, Parma, Italy, Report, EFSA J., 10, 2554, http://www.efsa. europa.eu/en/efsajournal/pub/2554 (accessed 26 February 2016).

Anon. (2012c), 'Statement on the use of animal-based measures to assess the welfare of animals', European Food Safety Authority, Parma, Italy, Report, EFSA J., 10, 2767, http://www.efsa. europa.eu/it/efsajournal/pub/2767 (accessed 26 February 2016).

Anon. (2013a), 'Dairy statistics. An insider's guide 2013', Agriculture \& Horticulture Development Board, Dairy division, Kenilworth, UK, Report, http://dairy.ahdb.org.uk/market-information/ farming-data/ (accessed 26 February 2016).

Anon. (2013b), 'Japan dairy farming', Japan Dairy Council, Tokyo, Japan, Report, http://www.dairy. co.jp/jp/engall.pdf (accessed 26 February 2016).

Anon. (2013c), 'World Dairy Situation 2013', International Dairy Federation, Brussels, Belgium, Bulletin 470, www.fil-idf.org/Public/Download.php?media=40634 (accessed 26 February 2016).

Anon. (2014a), 'Literature review on the welfare implications of dehorning and disbudding of cattle', American Veterinary Medical Association, Schaumburg, USA, https://www.avma.org/KB/ Resources/LiteratureReviews/(accessed 26 February 2016).

Anon. (2014b), 'Literature review on the welfare implications of tail docking of cattle', American Veterinary Medical Association, Schaumburg, USA, https://www.avma.org/KB/Resources/ LiteratureReviews/ (accessed 26 February 2016).

Anon. (2015a), 'Dairy statistics. An insider's guide 2015', Agriculture \& Horticulture Development Board, Dairy division, Kenilworth, UK, Report, http://dairy.ahdb.org.uk/market-information/ farming-data/ (accessed 26 February 2016).

Anon, (2015b), 'New Zealand Dairy Statistics 2014-15', Livestock Improvement Corporation, Hamilton, New Zealand and DairyNZ, Hamilton, New Zealand, Report, http://www.dairynz. co.nz/publications/dairy-industry/ (accessed 26 February 2016).

Anon. (2015c), 'Transparency 2015. Establishing Trust With Consumers', The Hartman Group, Inc., Bellevue, WA, USA, Report, http://store.hartman-group.com/sustainability-2015-transparency/ (accessed 26 February 2016).

Anon. (2016a), 'Antimicrobial resistance', Food and Agriculture Organization of the United Nations, Rome, Italy, Website, http://www.fao.org/antimicrobial-resistance/en/ (accessed 26 February 2016).

Anon. (2016b), 'Antimicrobial resistance', World Health Organization, Geneva, Switzerland, Website, http://www.who.int/drugresistance/en/ (accessed 26 February 2016).

Anon. (2016c), 'Antimicrobial resistance (AMR)', World Organisation for Animal Health, Paris, France, Website, http://www.oie.int/en/for-the-media/amr/ (accessed 26 February 2016).

Anon. (2016d), 'Attitudes of Europeans towards Animal Welfare. Special Eurobarometer 442', European Commission, Brussels, Belgium, Report, http://ec.europa.eu/COMMFrontOffice/ PublicOpinion/index.cfm/ResultDoc/download/DocumentKy/71348 (accessed 7 April 2016).

Anon. (2016e), 'EUROSTAT. Database', European Commission, Brussels, Belgium, Homepage, http:// ec.europa.eu/eurostat/data/database (accessed 26 February 2016). 
Anon. (2016f), 'FAOSTAT. Production', Food and Agriculture Organization of the United Nations, Rome, Italy, Website, http://faostat3.fao.org/ (accessed 26 February 2016).

Anon. (2016g), 'Farming Data', Agriculture \& Horticulture Development Board, Dairy division, Kenilworth, UK, Homepage, http://dairy.ahdb.org.uk/market-information/farming-data/ (accessed 26 February 2016).

Anon. (2016h), 'National Agricultural Statistics Service', NASS, United States Department of Agriculture, Washington, DC, USA, Homepage, http://www.nass.usda.gov/ (accessed 26 February 2016).

Anon. (2016i), 'Statistics Denmark', Homepage, http://www.dst.dk/en/ (accessed 26 February 2016).

Anon. (2016j), 'Transport of animal by land', OIE Platform on Animal Welfare for Europe, World Organisation for Animal Health, Paris, France, Website, http://rpawe.oie.int/index.php?id=283 (accessed 26 February 2016).

Anon. (2016k), 'World DataBank', World Bank, Washington, DC, USA, Website, http://databank. worldbank.org/data/ (accessed 26 February 2016).

Appleby, M. C., Mench, J. A., Olsson, I. A. S. and Hughes, B. O. (eds) (2011), Animal Welfare, 2nd ed., CAB International, Wallingford, UK and Cambridge, USA.

Appleby, M. C., Weary, D. M. and Sandøe, P. (eds) (2014), Dilemmas in Animal Welfare, $\mathrm{CAB}$ International, Wallingford, UK and Boston USA, http://www.cabi.org/cabebooks/ ebook/20143138804 (accessed 26 February 2016).

Atkinson S., Velarde A. and Algers B. (2013), Assessment of stun quality at commercial slaughter in cattle shot with captive bolt, Anim. Welf., 22, 473-81.

Barkema, H. W., Schukken, Y. H. and Lam, T. J. G. M. (1999), Management practices associated with the incidence rate of clinical mastitis, J. Dairy Sci., 82, 1643-54.

Barkema, H. W., von Keyserlingk, M. A. G., Kastelic, J. P., Lam, T. J. G. M., Luby, C. and Roy, J.-P. (2015), Changes in the dairy industry affecting dairy cattle health and welfare, J. Dairy Sci., 98, 7426-45.

Barker, Z. E., Leach, K. A., Whay, H. R., Bell, N. J. and Main, D. C. J. (2010), Assessment of lameness prevalence and associated risk factors in dairy herds in England and Wales, J. Dairy Sci., 93, 932-41.

Bascom, S. S. and Young, A. J. (1998), A summary of the reasons why farmers cull cows, J. Dairy. Sci., 81, 2299-305.

Bauman, D. E. and Currie, W. B. (1980), Partitioning of nutrients during pregnancy and lactation: A review of mechanisms involving homeostatic and homeorhesis, J. Dairy Sci., 63, 1514-29.

Bergman, M. A., Richert, R. M., Cicconi-Hogan, K. M., Gamroth, M. J., Schukken, Y. H., Stiglbauer, K. E. and Ruegg, P. L. (2014), Comparison of selected animal observations and management practices used to assess welfare of calves and adult dairy cows on organic and conventional dairy farms, J. Dairy Sci., 97, 4269-80.

Bewley, J. (2010), Precision Dairy Farming: advanced analysis solutions for future profitability, Proc. 1st North Am. Conf. Precision Dairy Manag., Toronto, Canada, 2-5 March 2010.

Bewley, J. M., Russell, R. A., Dolecheck, K. A., Borchers, M. R., Stone, A. E., Wadsworth, B. A., Mayo, L. M. and Tsai, I.-C. (2015), Precision dairy monitoring opportunities, limitations, and considerations, Proc.Western Dairy Manag. Conf., Reno, USA, 3-5 March 2015, http://www. wdmc.org/proceed.htm (accessed 26 February 2016).

Bickert, W. G. (2003), Dairy production systems, in D. R. Heldman (ed.), Encyclopedia of Agricultural, Food, and Biological Engineering, CRC Press Inc., pp. 162-4.

Bisinotto, R. S., Ribeiro, E. S. and Santos, J. E. P. (2014), Synchronisation of ovulation for management of reproduction in dairy cows, Animal, 8(Suppl. 1), 151-9.

Blokhuis, H., Keeling, L., Gavinelli, A. and Serratosa, J. (2008), Animal welfare's impact on the food chain, Trends Food Sci. Technol., 19, 75-83.

Blokhuis, H., Miele, M., Veissier, I. and Jones, B. (eds) (2013), Improving Farm Animal Welfare. Science and Society Working Together: The Welfare Quality Approach, Wageningen Academic Publishers, The Netherlands. 
Boissy, A. and Le Neindre, P. (1997), Behavioral, cardiac and cortisol responses to brief peer separation and reunion in cattle, Physiol. Behav., 61(5), 693-9.

Boogaard, B. K., Bock, B. B., Oosting, S. J., Wiskerke, J. S. C. and van der Zijpp, A. J. (2011), Social acceptance of dairy farming: the ambivalence between the two faces of modernity, J. Agric. Environ. Ethics, 24, 259-82.

Borderas, T. F. Rushen, J., von Keyserlingk, M. A. G. and de Passillé, A. M. B. (2009), Automated measurement of changes in feeding behavior of milk-fed calves associated with illness, J. Dairy Sci., 92, 4549-54.

Borkfelt, S., Kondrup, S., Röcklinsberg, H., Bjørkdahl, K. and Gjerris, M. (2015), Closer to nature? A critical discussion of the marketing of 'ethical' animal products, J. Agric. Environ. Ethics, 28, 1053-73.

Bouissou, M. F. and Andrieu, S. (1978), Établissement des relations préférentielles chez les bovins domestiques, Behav., 64, 148-57.

Bouissou, M. F., Boissy, A., Le Neindre, P. and Veissier, I. (2001), The social behaviour of cattle, in L. J. Keeling and H. W. Gonyou (eds), Social Behaviour in Farm Animals, CABI Publishing, Wallingford, UK, pp. 113-45.

Bracke, M. B. M. and Hopster, H. (2006), Assessing the importance of natural behavior for animal welfare, J. Agric. Environ. Ethics, 19, 77-89.

Bracke, M. B. M., Spruijt, B. M. and Metz, J. H. M. (1999), Overall animal welfare assessment reviewed. Part 1: Is it possible? Neth. J. Agric. Sci., 47, 279-91.

Broom, D. M. (2001), Coping, stress and welfare, in D. M. Broom (ed.), Coping with Challenge: Welfare in Animals including Humans, Dahlem University Press, Berlin, Germany, pp. 1-9.

Broom, D. M. (2010), Animal welfare: an aspect of care, sustainability, and food quality required by the public, J. Vet. Med. Educ., 37, 83-8.

Broom, D. M. (2014), Sentience and Animal Welfare, CAB International, Wallingford, UK and Boston, USA.

Broom, D. M. and Johnson, K. G. (2000), Stress and Animal Welfare, Kluwer Academic Publishers, Dordrecht, The Netherlands, Boston, USA and London, UK.

Bunting, L. D. and Galyean, M. L. (2015), Invited paper: customer and consumer confidence in the livestock industry - professional ethics, Prof. Anim. Sci., 31, 309-14.

Burke, C. R. and Verkerk, G. A. (2010), The development of reproductive management practices in New Zealand: what will the future hold in a consumer-focused, environmentally-conscious, export-driven marketplace? Soc. Reprod. Fertil. Suppl., 67, 341-55.

Burow, E., Thomsen, P. T., Sørensen, J. T. and Rousing, T. (2011), The effect of grazing on cow mortality in Danish dairy herds, Prev. Vet. Med., 100, 237-41.

Chanvallon, A., Coyral-Castel, S., Gatien, J., Lamy, J. M., Ribaud, D., Allain, C., Clément, P. and Salvetti, P. (2014), Comparison of three devices for the automated detection of estrus in dairy cows, Theriogenol., 82, 734-41.

Charlton, G. L., Rutter, S. M., East, M. and Sinclair, L. A. (2013), The motivation of dairy cows for access to pasture, J. Dairy Sci., 96, 4387-96.

Chesterton, R. N., Pfeiffer, D. U., Morris, R. S. and Tanner, C. M. (1989), Environmental and behavioural factors affecting the prevalence of foot lameness in New Zealand dairy herds - A case-control study, N. Z. Vet. J., 37, 135-42.

Clarkson, M. J., Downham, D. Y., Faull, W. B., Hughes, J. W., Manson, F. J., Merritt, J. B., Murray, R. D., Russell, W. B., Sutherst, J. E. and Ward, W. R. (1996), Incidence and prevalence of lameness in dairy cattle, Vet. Rec., 138, 563-7.

Dewey, C., Haley, C., Widowski, T., Friendship, R., Sunstrum, J. and Richardson, K. (2009), Using data collected for production or economic purposes to research production animal welfare: An epidemiological approach, J. Appl. Anim. Welf. Sci., 12, 105-13.

Dohoo, I. R., DesCôteaux, L., Leslie, K., Fredeen, A., Shewfelt, W., Preston, A. and Dowling, P. (2003), A meta-analysis review of the effects of recombinant bovine somatotropin 2. Effects on animal health, reproductive performance, and culling, Can. J. Vet. Res., 67, 252-64.

Edwards, S. A. (2002), A synthesis of animal bioethics teaching in agricultural and veterinary courses in Northern Europe, in Teaching Animal Bioethics in Agricultural and Veterinary Higher Education 
in Europe, Proc. Workshop of the EU Socrates Thematic Network for Agriculture, Forestry, Aquaculture and the Environment, Nancy, France, 23-24 May 2002, pp. 57-61, http://web04. univ-lorraine.fr/ENSAIA/marie/bioethics/workshop/toc.html (accessed 26 February 2016).

Edwards, S. A. (2008), Developments in animal welfare, Rev. electrón. vet, IX, BA030, http://www. veterinaria.org/revistas/redvet/n101008B.html (accessed 26 February 2016).

Engelbrecht Pedersen, R., Tind Sørensen, J., Skjøth, F., Hindhede, J. and Rousing Nielsen, T. (2009), How milk-fed dairy calves perform in stable versus dynamic groups, Livest. Sci., 121, 215-18.

Flower, F. C. and Weary, D. M. (2003), The effects of early separation on the dairy cow and calf, Anim. Welf., 12, 339-48.

Fraser, A. F. and Broom, D. M. (1990), Farm Animal Behaviour and Welfare, 3rd ed., CAB International, Wallingford, UK.

Fraser, D. (1999), Animal ethics and animal welfare science: bridging the two cultures, D.G.M. WoodGush Memorial Lecture, Appl. Anim. Behav. Sci., 65, 171-89.

Fraser, D. (2001), Farm animal production: Changing agriculture in a changing culture, J. Appl. Anim. Welf. Sci., 4, 175-90.

Fraser, D. (2008a), Understanding animal welfare, Acta Vet. Scand., 50(Suppl. 1), S1.

Fraser, D. (2008b), Understanding Animal Welfare: the Science in its Cultural Context, Wiley Blackwell, Chichester, UK.

Fraser, D., Duncan, I. J. H., Edwards, S. A., Grandin, T., Gregory, N. G., Guyonnet, V., Hemsworth, P. H., Huertas, S. M., Huzzey, J. M., Mellor, D. J., Mench, J. A., Špinka, M. and Whay, H. R. (2013), General Principles for the welfare of animals in production systems: The underlying science and its application, Vet. J., 198, 19-27.

Fraser, D., Weary, D. M., Pajor, E. A. and Milligan, B. N. (1997), A scientific conception of animal welfare that reflects ethical concerns, Anim, Welf., 6, 187-205.

Gaillard, C., Meagher, R. K., von Keyserlingk, M. A. G. and Weary, D. M. (2014), Social housing improves dairy calves' performance in two cognitive tests, PLOS ONE, 9, e90205.

Gjerris, M., Nielsen, M. E. J. and Sandøe, P. (2013), The Good, the Right and the Fair. An Introduction to Ethics, College Publications, London, UK.

Grandin, T. (1998), Handling methods and facilities to reduce stress on cattle, Vet. Clin. North Am.: Food Anim. Pract., 14, 325-41.

Grandin, T. (2013), Making slaughterhouses more humane for cattle, pigs, and sheep, Annu. Rev. Anim. Biosci., 1, 491-512.

Grave, K., Greko, C., Kvaale, M. K., Torren-Edo, J., Mackay, D., Muller, A. and Moulin, G. (2012), Sales of veterinary antibacterial agents in nine European countries during 2005-09: trends and patterns, J. Antimicrob. Chemother., 67, 3001-8.

Gregory, N. G., von Wenzlawowicz, M., von Holleben, K., Fielding, H. R., Gibson, T. J., Mirabito, L. and Kolesar, R. (2012), Complications during shechita and halal slaughter without stunning in cattle, Anim. Welf., 21 (Suppl. 2), 81-6.

Gulliksen, S. M., Lie, K. I., Løken, T. and Østerås, O. (2009), Calf mortality in Norwegian dairy herds, J. Dairy Sci., 92, 2782-95.

Hanlon, A. (2008), Animal welfare in veterinary medicine education, Rev. electrón. vet, IX, BA022, http://www.veterinaria.org/revistas/redvet/n101008B.html (accessed 26 February 2016).

Hardeman, E. and Jochemsen, H. (2012), Are there ideological aspects to the modernization of agriculture? J. Agric. Environ. Ethics, 25, 657-74.

Harrison, R. (1964), Animal Machines: The New Factory Farming Industry, Vincent Stuart Publishers. London, UK.

Haskell, M. J., Rennie, L. J., Bowell, V. A., Bell, M. J. and Lawrence, A. B. (2006), Housing system, milk production, and zero-grazing effects on lameness and leg injury in dairy cows, J. Dairy Sci., 89, 4259-66.

Haynes, R. P. (2008), Animal Welfare. Competing Conceptions and Their Ethical Implications, Springer, New York, USA.

Håkansson, N. (2012), 'Network analysis and optimization of animal transports', Linköping Studies in Science and Technology, Dissertation 1434, Linköping University, Linköping, Sweden, 
http://liu.diva-portal.org/smash/record.jsf?pid=diva2\%3A514097\&dswid=-7653 (accessed 26 February 2016).

Heath, C. A. E., Lin, Y., Mullan, S., Browne, W. J. and Main, D. C. J. (2014), Implementing Welfare Quality $\AA$ in UK assurance schemes: evaluating the challenges, Anim. Welf., 23, 95-107.

Heerwagen, L. R., Mørkbak, M. R., Denver, S., Sandøe, P. and Christensen, T. (2015), The role of quality labels in market-driven animal welfare, J. Agric. Environ. Ethics, 28, 67-84.

Hemsworth, P. H. (2003), Human-animal interactions in livestock production, Appl. Anim. Behav. Sci., 81, 185-98.

Hemsworth, P. H. (2009), Impact of human-animal interactions on the health, productivity and welfare of farm animals, in A. Aland and F. Madec (eds), Sustainable Animal Production. The Challenges and Potential Developments for Professional Farming, Wageningen Academic Publ., Wageningen, The Netherlands, pp. 57-68.

Hemsworth, P. H. and Coleman, G. J. (2011), Human-Livestock Interactions: The Stockperson and the Productivity and Welfare of Intensively Farmed Animals, 2nd ed., Wallingford, UK and Cambridge, USA, http://www.cabi.org/cabebooks/ebook/20103380749 (accessed 26 February 2016).

Hemsworth, P. H., Coleman, G. J., Barnett, J. L., Borg, S. and Dowling, S. (2002), The effects of cognitive behavioral intervention on the attitude and behavior of stockpersons and the behavior and productivity of commercial dairy cows, J. Anim. Sci., 80, 68-78.

Hemsworth, P. H., Rice, M., Karlen, M. G., Calleja, L. Barnett, J. L., Nash, J. and Coleman, G. J. (2011), Human-animal interactions at abattoirs: Relationships between handling and animal stress in sheep and cattle, Appl. Anim. Behav. Sci., 135, 24-33.

Hernandez-Mendo, O., von Keyserlingk, M. A. G., Veira, D. M. and Weary, D. M. (2007), Effects of pasture on lameness in dairy cows, J. Dairy Sci., 90, 1209-14.

Houe, H., Gardner, I. A. and Rosenbaum Nielsen, L. (2011), Use of information on disease diagnoses from databases for animal health economic, welfare and food safety purposes: strengths and limitations of recordings, Acta Vet. Scand., 53(Suppl. 1), S7.

Hötzel, M. J. (2014), Improving farm animal welfare: is evolution or revolution needed in production systems?, in M. C. Appleby, D. M. Weary and P. Sandøe (eds), Dilemmas in Animal Welfare, CAB International, Wallingford, UK and Boston USA, pp. 67-84, http://www.cabi.org/cabebooks/ ebook/20143138804 (accessed 26 February 2016).

Hultgren, J., Wiberg, S., Berg, L., Cvek, K. and Lunner Kolstrup, C. (2014), Cattle behaviours and stockperson actions related to impaired animal welfare at Swedish slaughter plants, Appl. Anim. Behav. Sci., 152, 23-37.

Ingvartsen, K. L., Dewhurst, R. J. and Friggens, N. C. (2003), On the relationship between lactational performance and health: is it yield or metabolic imbalance that cause production diseases in dairy cattle? A position paper, Livest. Prod. Sci., 83, 277-308.

Jensen, P. (2006), Domestication - from behaviour to genes and back again, Appl. Anim. Behav. Sci., 97, 3-15.

Johnsen, J. F., de Passille, A. M., Mejdell, C. M., Bøe, K. E., Grøndahl, A. M., Beaver, A., Rushen, J. and Weary, D. M. (2015), The effect of nursing on the cow-calf bond, Appl. Anim. Behav. Sci., $163,50-7$.

Johnsen, J. F., Zipp, K. A., Kälber, T., de Passillé, A. M., Knierim, U., Barth, K. and Mejdell, C. M. (2016), Is rearing calves with the dam a feasible option for dairy farms? - Current and future research, Appl. Anim. Behav. Sci., in press.

KilBride, A. L., Mason, S. A., Honeyman, P. C., Pritchard, D. G., Hepple, S. and Green, L. E. (2012), Associations between membership of farm assurance and organic certification schemes and compliance with animal welfare legislation, Vet. Rec., 170, 152-9.

Krohn, C. C. (2001), Effects of different suckling systems on milk production, udder health, reproduction, calf growth and some behavioural aspects in high producing dairy cows - a review, Appl. Anim. Behav. Sci., 72, 271-80.

Laxminarayan, R., Duse, A., Wattal, C., Zaidi, A. K. M., Wertheim, H. F. L., Sumpradit, N., Vlieghe, E., Levy Hara, G., Gould, I. M., Goossens, H., Greko, C., So, A. D., Bigdeli, M., Tomson, G., Woodhouse, W., Ombaka, E., Quizhpe Peralta, A., Naz Qamar, F., Mir, F., Kariuki, S., Bhutta, Z. A., 
Coates, A., Bergstrom, R., Wright, G. D., Brown, E. D. and Cars, O. (2013), Antibiotic resistance - the need for global solutions, Lancet Infect. Dis., 13, 1057-98.

Legrand, A. L., von Keyserlingk, M. A. G. and Weary, D. M. (2009), Preference and usage of pasture versus free-stall housing by lactating dairy cattle, J. Dairy Sci., 92, 3651-8.

Lensink, B. J., Raussi, S., Boivin, X., Pyykkönen, M. and Veissier, I. (2001), Reactions of calves to handling depend on housing condition and previous experience with humans, Appl. Anim. Behav. Sci., 70, 187-99.

Loizzo, A., Loizzo, S. and Capasso, A. (2009), Neurobiology of pain in children: an overview, Open Biochem. J., 3, 18-25.

Lund, V. (2006), Natural living - a precondition for animal welfare in organic farming, Livest. Sci., 100, 71-83.

Lund, V. and Röcklinsberg, H. (2001), Outlining a conception of animal welfare for organic farming systems, J. Agric. Environ. Ethics, 14, 391-424.

Lundmark, F., Berg, L., Wahlberg, B. and Röcklinsberg, H. (2015), 'One animal is no animal' consequences of measuring animal welfare at herd level, in D. E. Dumitras, I. M. Jitea and S. Aerts (eds), Know your Food. Food Ethics and Innovation, Proc. EurSafe Congr., Cluj-Napoca, Romania, 28-30 May 2015, pp. 31-5.

Lusk, J. L. and Norwood, F. B. (2008), A survey to determine public opinion about the ethics and governance of farm animal welfare, J. Am. Vet. Med. Assoc., 233, 1121-6.

Lürzel, S., Münsch, C., Windschnurer, I., Futschik, A., Palme, R. and Waiblinger, S. (2015), The influence of gentle interactions on avoidance distance towards humans, weight gain and physiological parameters in group-housed dairy calves, Appl. Anim. Behav. Sci., 172, 9-16.

Main, D. C., Thornton, P. and Kerr, K. (2005), Teaching animal welfare science, ethics, and law to veterinary students in the United Kingdom, J. Vet. Med. Educ., 32, 505-8.

Mclnerney, J. P. (2002), Animal welfare: ethics, economics and productivity, livestock improvement corporation lecture, Proc. NZ Soc. An. Prod., 62, 340-7.

Medrano-Galarza, C., Gibbons, J., Wagner, S., de Passillé, A. M. and Rushen, J. (2012), Behavioral changes in dairy cows with mastitis, J. Dairy Sci., 95, 6994-7002.

Medugorac, I., Seichter, D., Graf, A., Russ, I., Blum, H., Göpel, K. H., Rothammer, S., Förster, M. and Krebs, S. (2012), Bovine polledness - an autosomal dominant trait with allelic heterogeneity, PLoS ONE, 7, e39477.

Mellor, D. J. and Bayvel, A. C. D. (2008), New Zealand's inclusive science-based system for setting animal welfare standards, Appl. Anim. Behav. Sci., 113, 313-29.

Mellor, D. J. and Bayvel, A. C. D. (eds) (2014), Animal welfare: focusing on the future, World Organisation for Animal Health, Paris, France, Rev. Sci. Tech. Off. Int. Epiz., 33, 1-328, http:// web.oie.int/boutique/index.php?page=ficprod\&id_produit=1307\&fichrech=1\&lang=en (accessed 26 February 2016).

Mellor, D. J., Patterson-Kane, E. and Stafford, K. J. (2009), The Sciences of Animal Welfare, WileyBlackwell, Wheathampstead, UK.

Mench, J. A. (2008), Farm animal welfare in the U.S.A.: Farming practices, research, education, regulation, and assurance programs, Appl. Anim. Behav. Sci., 113, 298-312.

Menke, C., Waiblinger, S., Fölsch, D. W. and Wiepkema, P. R. (1999), Social behaviour and injuries of horned cows in loose housing systems, Anim. Welf., 8, 243-58.

Müller-Graf, C., Candiani, C., Barbieri, S., Ribo, O., Afonso, A., Aiassa, E., Have, P., Correia, S., De Massis, F., Grudnik, T. and Serratosa, J. (2008), Risk assessment in animal welfare - EFSA approach, Proc. 6th World Congr. Altern. Anim. Use Life Sci., Tokyo, Japan, 21-25 August 2007, AATEX 14, Special Issue, 789-94, http://altweb.jhsph.edu/wc6/paper789.pdf (accessed 26 February 2016).

Nyman, A.-K., Lindberg, A. and Hallén Sandgren, C. (2011), Can pre-collected register data be used to identify dairy herds with good cattle welfare? Acta Vet. Scand., 53 (Suppl. 1), S8.

Oltenacu, P. A. and Broom, D. M. (2010), The impact of genetic selection for increased milk yield on the welfare of dairy cows, Anim. Welf., 19(S), 39-49.

Oltenacu, P. A., Frick, A. and Lindhé, B. (1990), Epidemiological study of several clinical diseases, reproductive performance and culling in primiparous Swedish cattle, Prev. Vet. Med., 9, 59-74. 
Paton, M. W., Martin, P. A. J. and Fisher, A. D. (2013), Risk assessment principles in evaluation of animal welfare, Anim. Welf., 22, 277-85.

Popescu, S., Borda, C., Diugan, E. A., Niculae, M., Stefan, R. and Sandru, C. D. (2014), The effect of the housing system on the welfare quality of dairy cows, Ital. J. Anim. Sci., 13, 15-22.

Popescu, S., Borda, C., Diugan, E. A., Spinu, M., Groza, I. S. and Sandru, C. D. (2013), Dairy cows welfare quality in tie-stall housing, system with or without access to exercise, Acta Vet. Scand., 55, 43.

Probst, J. K., Spengler Neff, A., Leiber, F., Kreuzer, M. and Hillmann, E. (2012), Gentle touching in early life reduces avoidance distance and slaughter stress in beef cattle, Appl. Anim. Behav. Sci., 139, 42-9.

Proudfoot, K. L., Weary, D. M. and von Keyserlingk, M. A. G. (2012), Linking the social environment to illness in farm animals, Appl. Anim. Behav. Sci., 138, 203-15.

Pryce, J. E. and Veerkamp, R. F. (2001), The incorporation of fertility indices in genetic improvement programmes, in M. G. Diskin (ed.), Fertility in the High-Producing Dairy Cow, Proc. Occ. Mtg. Galway, Ireland, 20-22 September 1999, BSAS Occ. Publ., 26, 237-49.

Rauw, W. M., Kanis, E., Noordhuizen-Stassen, E. N. and Grommers, F. J. (1998), Undesirable side effects of selection for high production efficiency in farm animals: a review, Livest. Prod. Sci., $56,15-33$.

Rodríguez-Martínez, H. Hultgren, J., Båge, R., Bergqvist, A. -S., Svensson, C., Bergsten, C., Lidfors, L., Gunnarsson, S., Algers, B., Emanuelson, U., Berglund, B., Andersson, G., Lindhé, B., Stålhammar, H. and Gustafsson, H. (2008), Reproductive performance in high-producing dairy cows: can we sustain it under current practice? IVIS Rev.Vet. Med., R01, R0108, 1-23.

Roex, J. and Miele, M. (eds) (2005), Farm Animal Welfare Concerns. Consumers, Retailers and Producers, Welfare Quality Reports No. 1, School of City and Regional Planning, Cardiff University, Cardiff, UK, http://www.welfarequality.net/everyone/34056/5/0/22 (accessed 26 February 2016).

Rollin, B. E. (1990), The Unheeded Cry, Oxford University Press, Oxford, UK.

Rollin, B. E. (1995), Farm Animal Welfare: Social, Bioethical, and Research Issues, lowa State Univ. Press, Ames, USA.

Rouha-Mülleder, C., Iben, C., Wagner, E., Laaha, G., Troxler, J. and Waiblinger, S. (2009), Relative importance of factors influencing the prevalence of lameness in Austrian cubicle loose-housed dairy cows, Prev. Vet. Med., 92, 123-33.

Rushen, J., de Passillé, A. M., von Keyserlingk, M. A. G. and Weary, D. M. (2008), The Welfare of Cattle, Springer, Dordrecht, The Netherlands.

Rushen, J., Taylor, A. A. and de Passille, A. M. (1999), Domestic animals' fear of humans and its effect on their welfare, Appl. Anim. Behav. Sci., 65, 285-303.

Rutherford, K. M. D., Langford, F. M., Jack, M. C., Sherwood, L., Lawrence, A. B. and Haskell, M. J. (2008), Hock injury prevalence and associated risk factors on organic and nonorganic dairy farms in the United Kingdom, J. Dairy Sci., 91, 2265-74.

Rutten, C. J., Velthuis, A. G. J., Steeneveld, W. and Hogeveen, H. (2013), Invited review: Sensors to support health management on dairy farms, J. Dairy Sci., 96, 1928-52.

Sandøe, P., Christiansen, S. B. and Appleby, M. C. (2003), Farm animal welfare: the interaction of ethical questions and animal welfare science, Anim. Welf., 12, 469-78.

Schuenemann, G. M., Bas, S. Gordon, E. and Workman, J. D. (2013), Dairy calving management: Description and assessment of a training program for dairy personnel, J. Dairy Sci., 96, 2671-80.

Schuppli, C. A., von Keyserlingk, M. A. G. and Weary, D. M. (2014), Access to pasture for dairy cows: Responses from an online engagement, J. Anim. Sci., 92, 5185-92.

Simensen, E., Østerås, O., Bøe, K. E., Kielland, C., Ruud, L. E. and Næss, G. (2010), Housing system and herd size interactions in Norwegian dairy herds; associations with performance and disease incidence, Acta Vet. Scand., 52, 14.

Smulders, F. J. M. (2009), A practical approach to assessing risks for animal welfare - methodological considerations, in F. J. M. Smulders and B. Algers (eds), Welfare of Production Animals: Assessment and Management of Risks, Food safety assurance and veterinary public health, vol. 5, Wageningen Academic Publishers, Wageningen, The Netherlands, pp. 239-74. 
Stafford, K. J. and Mellor, D. J. (2005), Dehorning and disbudding distress and its alleviation in calves, Vet. J., 169, 337-49.

Stěhulová, I., Lidfors, L. and Špinka, M. (2008), Response of dairy cows and calves to early separation: Effect of calf age and visual and auditory contact after separation, Appl. Anim. Behav. Sci., 110, 144-65.

Stock, M. L., Baldridge, S. L., Griffin, D. and Coetzee, J. F. (2013), Bovine dehorning. Assessing pain and providing analgesic management, Vet. Clin. North Am.: Food Anim. Pract., 29, 103-33.

Sutherland, M. A. and Tucker, C. B. (2011), The long and short of it: A review of tail docking in farm animals, Appl. Anim. Behav. Sci., 135, 179-91.

Svensson, C. and Jensen, M. B. (2007), Identification of diseased calves by use of data from automatic milk feeders, J. Dairy Sci., 90, 994-7.

Svensson, C. and Liberg, P. (2006), The effect of group size on health and growth rate of Swedish dairy calves housed in pens with automatic milk-feeders, Prev. Vet. Med., 73, 43-53.

Svensson, C., Linder, A. and Olsson, S.-O. (2006), Mortality in Swedish dairy calves and replacement heifers, J. Dairy Sci., 89, 4769-77.

Svensson, C., Lundborg, K., Emanuelson, U. and Olsson, S. O. (2003), Morbidity in Swedish dairy calves from birth to 90 days of age and individual calf-level risk factors for infectious diseases, Prev. Vet. Med., 58, 179-97.

Tannenbaum, J. (1991), Ethics and animal welfare: the inextricable connection, J. Am. Vet. Med. Assoc., 198, 1360-76.

Terlouw, E. M. C., Arnould, C., Auperin, B., Berri, C., Le Bihan-Duval, E., Deiss, V., Lefévre, F., Lensink, B. J. and Mounier, L. (2008), Pre-slaughter conditions, animal stress and welfare: current status and possible future research, Anim., 2, 1501-17.

Thomsen, P. T., Østergaard, S., Sørensen, J. T. and Houe, H. (2007), Loser cows in Danish dairy herds: definition, prevalence and consequences, Prev. Vet. Med., 79, 116-35.

Thorpe, W. H. (1965), The assessment of pain and distress in animals, in F. W. Rogers Brambell (ed.), 'Report of the technical committee to enquire into the welfare of animals kept under intensive livestock husbandry systems', Appendix III, Her Majesty's Stationary Office, London, UK, pp. 71-9.

Uetake, K. (2013), Newborn calf welfare: a review focusing on mortality rates, Anim. Sci. J., 84, 101-5.

Valníčková, B., Stěhulová, I., Šárová, R. and Špinka, M. (2015), The effect of age at separation from the dam and presence of social companions on play behavior and weight gain in dairy calves, J. Dairy Sci., 98, 5545-56.

Van Nuffel, A., Zwertvaegher, I., Pluym, L, Van Weyenberg, S., Thorup, V. M., Pastell, M., Sonck, B. and Saeys, W. (2015), Lameness detection in dairy cows: Part 1. How to distinguish between non-lame and lame cows based on differences in locomotion or behavior, Anim., 5, 838-60.

Vanhonacker, F., Verbeke, W., Van Poucke, E. and Tuyttens, F. A. M. (2008), Do citizens and farmers interpret the concept of farm animal welfare differently? Livest. Sci., 116, 126-36.

VanRaden, P. M. (2004), Selection on net merit to improve lifetime profit, J. Dairy Sci., 87, 3125-31.

Vasseur, E., Borderas, F., Cue, R. I., Lefebvre, D., Pellerin, D., Rushen, J., Wade, K. M. and de Passillé, A. M. (2010a), A survey of dairy calf management practices in Canada that affect animal welfare, J. Dairy Sci., 93, 1307-15.

Vasseur, E., Rushen, J., de Passillé, A. M., Lefebvre, D. and Pellerin, D. (2010b), An advisory tool to improve management practices affecting calf and heifer welfare on dairy farms, J. Dairy Sci., 93, 4414-26.

Veerkamp, R. F., Beerda, B. and van der Lende, T. (2003), Effects of genetic selection for milk yie1d on energy balance, levels of hormones, and metabolites in lactating cattle, and possible links to reduced fertility, Livest. Prod. Sci., 83, 257-75.

Veissier, I., Andanson, S., Dubroeucq, H. and Pomiès, D. (2008), The motivation of cows to walk as thwarted by tethering, J. Anim. Sci., 86, 2723-9.

Veissier, I., Butterworth, A., Bock, B. and Roe, E. (2008), European approaches to ensure good animal welfare, Appl. Anim. Behav. Sci., 113, 279-97. 
Velarde, A., von Holleben, K. and Anil, H. (2010), 'Assessment of the incidence and scale of current religious slaughter practices', DIALREL project, Factsheet, http://www.dialrel.eu/dialrel-results. html (accessed 26 February 2016).

Velarde, A., Rodriguez, P., Dalmau, A., Fuentes, C., Lloncha, P., von Holleben, K. V., Anil, M. H., Lambooij, J. B., Pleiter, H., Yesildere, T. and Cenci-Goga, B. T. (2014), Religious slaughter: evaluation of current practices in selected countries, Meat Sci., 96, 278-87.

Verhoog, H. (2000), Defining positive welfare and animal integrity, in M. Hovi and R. Garcia Trujillo (eds), Diversity of Livestock Systems and Definition of Animal Welfare, Proc. 2nd Workshop Network Anim. Health Welfare Organ. Agric., Cordoba, Spain, 8-11 January 2000, pp. 108-19, http://www.veeru.reading.ac.uk/organic/proc/proceedings.htm (accessed 26 February 2016).

Von Wenzlawowicz, M., von Holleben, K. and Eser, E. (2012), Identifying reasons for stun failures in slaughterhouses for cattle and pigs: a field study, Anim. Welf., 21(Suppl. 2), 51-60.

Waiblinger, S., Boivin, X., Pedersen, V., Tosi, M. V., Janczak, A. M., Visser, E. K. and Jones, R. B. (2006), Assessing the human-animal relationship in farmed species: acritical review, Appl. Anim. Behav. Sci., 101, 185-242.

Waiblinger, S. and Menke, C. (1999), Influence of herd size on human-cow relationships, Anthrozoös, $12,240-7$.

Waiblinger, S., Menke, C., Korff, J. and Bucher, A. (2004), Previous handling and gentle interactions affect behaviour and heart rate of dairy cows during a veterinary procedure, Appl. Anim. Behav. Sci., 85, 31-42.

Washburn, S. P., White, S. L., Green Jr., J. T. and Benson, G. A. (2002), Reproduction, mastitis, and body condition of seasonally calved Holstein and Jersey cows in confinement or pasture systems, J. Dairy Sci., 85, 105-11.

Webster, J. (2005), Animal Welfare: Limping Towards Eden, Blackwell Publishing, Oxford, UK.

Webster, J. (ed.) (2011), Management and Welfare of Farm Animals. UFAW Farm Handbook, 5th ed., Wiley-Blackwell, Oxford, UK.

You, X., Li, Y., Zhang, M., Yan, H. and Zhao, R. (2014), A survey of Chinese citizens' perceptions on farm animal welfare, PLoS ONE, 9, e109177.

Zogby, J. (2003), 'Nationwide Views on the Treatment of Farm Animals. Report submitted to the Animal Welfare Trust, USA', Zogby International Research LLC, Utica, NY, USA, http://civileats. com/wp-content/uploads/2009/09/AWT-final-poll-report-10-22.pdf (accessed 26 February 2016).

Zuliani, A., Massolo, A., Lysyk, T., Johnson, G., Marshall, S., Berger, K. and Cork, S. C. (2015), Modelling the northward expansion of Culicoides sonorensis (Diptera: Ceratopogonidae) under future climate scenarios, PLOS ONE, 10, e0130294. 